This document is the Accepted Manuscript version of a Published Work that appeared in final form in Langmuir, copyright (c) American Chemical Society after peer review and technical editing by the publisher.

To access the final edited and published work see:

https://dx.doi.org/10.1021/acs.langmuir.5b04622 


\title{
Co-Cu nanoparticles: synthesis by galvanic replacement and phase rearrangement during catalytic activation
}

\author{
Raquel Nafria,,$^{\dagger}$ Aziz Genç, ${ }^{\complement}$ Maria Ibáñez, ${ }^{\dagger}$ Jordi Arbiol, ${ }^{\rrbracket}, \S$ Pilar Ramírez de la Piscina, ${ }^{¥}$ Narcís \\ Homs, ${ }^{*}+, *$ Andreu Cabot, ${ }^{*}+, \xi$ \\ ${ }^{\dagger}$ Catalonia Institute for Energy Research, IREC, 08930 Sant Adrià del Besos, Spain \\ "Institut Català de Nanociència i Nanotecnologia, ICN2, Campus de la UAB, 08193 Bellaterra, \\ Spain \\ ${ }^{\S}$ Institució Catalana de Recerca i Estudis Avançats, ICREA, 08010 Barcelona, Spain \\ ¥ Departament de Química Inorgànica and Institut de Nanociència i Nanotecnologia, Universitat \\ de Barcelona, 08028 Barcelona, Spain
}

\begin{abstract}
KEYWORDS: catalysis, colloidal synthesis, bimetallic nanoparticles, $\mathrm{Co}-\mathrm{Cu}$ catalysts, $\mathrm{CO}_{2}$ hydrogenation
\end{abstract}

\begin{abstract}
The control of the phase distribution in multicomponent nanomaterials is critical to optimize their catalytic performance. In this direction, while impressive advances have been achieved in the last decade in the synthesis of multicomponent nanoparticles and nanocomposites, element rearrangement during catalyst activation has been frequently overseen. Here, we present a facile galvanic replacement-based procedure to synthesize $\mathrm{Co} @ \mathrm{Cu}$ nanoparticles with narrow size and composition distributions. We further characterize their phase arrangement before and after catalytic activation. When oxidized at $350{ }^{\circ} \mathrm{C}$ in air to remove
\end{abstract}


organics, $\mathrm{Co} @ \mathrm{Cu}$ core-shell nanostructures oxidize to polycrystalline $\mathrm{CuO}-\mathrm{Co}_{3} \mathrm{O}_{4}$ nanoparticles with randomly distributed $\mathrm{CuO}$ and $\mathrm{Co}_{3} \mathrm{O}_{4}$ crystallites. During a posterior reduction treatment in $\mathrm{H}_{2}$ atmosphere, $\mathrm{Cu}$ precipitates in a metallic core and Co migrates to the nanoparticle surface to form $\mathrm{Cu} @$ Co core-shell nanostructures. The catalytic behavior of such $\mathrm{Cu} @ \mathrm{Co}$ nanoparticles supported on mesoporous silica was further analyzed toward $\mathrm{CO}_{2}$ hydrogenation in real working conditions.

\section{INTRODUCTION}

The rational design of more active, selective and durable catalysts requests for a deeper fundamental understanding of the influence of each material parameter on its performance. This ambitious goal requires engineering model catalysts with accurately tuned parameters and that can be tested in real working conditions. The availability of such real model systems is critical to overcome the material and pressure gaps partially disconnecting fundamental surface science studies from real industrial catalysts. ${ }^{1-4}$ In this framework, colloidal synthesis routes allow producing large amounts of nanoparticles (NPs) with a unique control over composition, crystal phase, particle size and surface facets. ${ }^{5-9}$ Such colloidal NPs can be supported on or assembled into high surface area materials, and the resulting nanocomposites can be used as real catalytic model systems to investigate the influence of material parameters in real reaction conditions. . $^{2,10-12}$ This strategy is especially interesting in multi-metal catalysts, where not only the parameters of each individual component, but also the distribution of these components, in the form of independent entities, multi-metal alloys, Janus/dimer or core-shell NPs, have a crucial role on the final catalytic performance. ${ }^{1-4,13}$ 
A particularly interesting catalytic reaction involving multicomponent heterogeneous catalyst and strongly influenced by the metal size and distribution is $\mathrm{CO}_{2}$ hydrogenation:

$$
\mathrm{CO}_{2}+\mathrm{xH}_{2} \rightarrow \mathrm{C}_{\mathrm{n}} \mathrm{H}_{2 \mathrm{n}+1} \mathrm{OH}+\mathrm{C}_{\mathrm{n}} \mathrm{H}_{(2 \mathrm{n} \pm 2)}+\ldots
$$

The social and economic interest of $\mathrm{CO}_{2}$ hydrogenation resides both on its potential to mitigate $\mathrm{CO}_{2}$ concentration in the atmosphere, and on the fact that $\mathrm{CO}_{2}$ can be a feedstock of $\mathrm{C}_{2+}$ hydrocarbons and alcohols. Moreover $\mathrm{CO}_{2}$ is a non-toxic, non-corrosive, and non-flammable reactant, which can be easily stored and transported in liquid form under mild pressure. ${ }^{14-18}$

Among the numerous candidates for $\mathrm{CO}_{2}$ hydrogenation, cobalt-copper catalysts are one of the most selective and cost-effective option. ${ }^{19-26}$ Joint effects of $\mathrm{Co}$ and $\mathrm{Cu}$ can be understood on the basis of the properties of each single element catalyst. In the presence of $\mathrm{H}_{2}, \mathrm{Co}$ is able to dissociate $\mathrm{CO}$ and $\mathrm{CO}_{2}$ and to hydrogenate the resulting surface carbon species into hydrocarbons. $^{27,28}$ Thus, it is used for the synthesis of medium chain and long-chain hydrocarbons in the Fischer-Tropsch (FT) process. ${ }^{29}$ On the other hand, Cu molecularly adsorbs $\mathrm{CO}_{2}$ and $\mathrm{CO}$ with a slow dissociation rate, which allows the incorporation of oxygen in the final hydrogenated products, and thus the formation of alcohols. ${ }^{27,28,30}$ Therefore, $\mathrm{Cu}$ is used in the synthesis of methanol from $\mathrm{CO}_{2}$ hydrogenation or syngas. ${ }^{31-34}$

Previous studies on the use of $\mathrm{Cu}$ or $\mathrm{Co}$ catalysts for $\mathrm{CO}_{2}$ hydrogenation and $\mathrm{FT}$ reactions demonstrated that parameters such as NP size strongly influence their performance. In particular, cobalt activity decreased rapidly when the NP size was reduced below $10 \mathrm{~nm}$, although no size effect was observed on the selectivity. ${ }^{35-39}$ On the other hand, the turnover frequencies for methanol formation from $\mathrm{CO}_{2}$ hydrogenation of $\mathrm{Cu}$ NPs increased as NP size was reduced. ${ }^{40}$ Beyond the properties of each individual catalytic material, the distribution of the active phases is also key to determine the composition of the $\mathrm{FT}$ and $\mathrm{CO}_{2}$ hydrogenation product stream. As an 
example from the much better studied FT reaction, N. D. Subramanian et al. found that Co@Cu core-shell NPs were more active than $\mathrm{Co}-\mathrm{Cu}$ dimer NPs in the $\mathrm{CO}$ hydrogenation, but $\mathrm{Co}-\mathrm{Cu}$ NPs were more selective than Co@Cu NPs to the formation of ethanol and higher oxygenates. ${ }^{27}$ Besides, G. Liu et al. reported that the hydrogenation of CO over Co@Cu NPs favored alcohol synthesis, while $\mathrm{Cu} @$ Co NPs generated more hydrocarbons. ${ }^{24}$ Recently, G. Prieto et al. demonstrated that preventing the copper segregation on $\mathrm{Co}-\mathrm{Cu}$ alloys increased the $\mathrm{C}_{2+}$ alcohols selectivity in the FT process. ${ }^{41}$

While catalytic performance is extremely sensitive to surface composition of the catalyst, an important challenge when dealing with multi-metallic NPs is the characterization and understanding of the physical and chemical restructuring of the catalyst taking place during activation treatments and catalytic test. This is particularly crucial in Co-Cu NPs and in general in most transition metals, where activation/reduction processes inducing major chemical and structural changes are absolutely necessary, and major structural and chemical changes can take place during these processes as observed by Y. Xiang et al., ${ }^{25} \mathrm{~S}$. Carenco et al. ${ }^{42}$ and S. Alayoglu et al. ${ }^{28}$. Nevertheless, due to the difficulties in producing catalysts with well-defined active phase distribution, shape and size, the segregation and compositional re-organization of these catalytically active phases during catalyst activation is frequently overseen.

We present here a new synthetic strategy to produce monodisperse $\mathrm{Co}-\mathrm{Cu}$ NPs with controlled metal ratios based on a galvanic replacement reaction. We used these NPs to gain understanding on the structural and chemical changes taking place before and after the thermal treatments used for the catalyst preparation and activation. We further analyze the catalytic behavior of these NPs supported on mesoporous silica toward $\mathrm{CO}_{2}$ hydrogenation. 


\section{EXPERIMENTAL}

Chemicals: Cobalt carbonyl $\left(\mathrm{Co}_{2}(\mathrm{CO})_{8}, \geq 90 \%\right)$, copper(I) chloride (99.99\%), copper (I) acetate (CuOAc, 97\%), 1,2 anhydrous dichlorobenze (DCB, 99\%) and oleylamine (OLA, tech. 70\%) were purchased from Sigma Aldrich. Trioctylphosphine oxide (TOPO, 99\%) was purchased from Stream Chemicals, trioctylamine (TOA, 97\%) from Acros, and tetradecylphosphonic acid (TDPA, 97\%) from PlasmaChem GmbH. All products were used without further purification, except for OLA which was distilled. Analytical grade isopropanol, ethanol, hexane were purchased from Panreac. Stock solutions of copper (I) chloride in OLA $(0.25 \mathrm{M})$ were prepared by dissolving $2.5 \mathrm{~g}$ of $\mathrm{CuCl}$ in $100 \mathrm{~mL}$ of OLA. All NP preparations were carried out using standard air-free techniques: a vacuum/dry-argon Schlenk line was used for the synthesis and an argon-filled glovebox for storing and handling air- and moisturesensitive chemicals.

Cobalt nanoparticles: Co NPs were produced following a similar procedure as the one described previously by V. Puntes et al., ${ }^{43}$ but replacing oleic acid by OLA. In a typical synthesis, $0.1 \mathrm{~g}$ of TOPO, $15 \mathrm{~mL}$ of DCB and $0.3 \mathrm{~mL}$ of OLA were degassed in a $250 \mathrm{~mL}$ threeneck flask for $30 \mathrm{~min}$ in Ar. Then the solution was heated to $180{ }^{\circ} \mathrm{C}$. At this temperature, $0.54 \mathrm{~g}$ of $\mathrm{Co}_{2}(\mathrm{CO})_{8}$ dissolved in $3 \mathrm{~mL}$ of DCB were rapidly injected. After 10 minutes, the solution was cooled down to room temperature. Co NPs were purified by multiple precipitation/re-dispersion steps using isopropanol as a non-solvent and hexane as solvent.

Copper nanoparticles: $\mathrm{Cu}$ NPs were prepared following the procedure reported by Yang et al. ${ }^{44}$ In a typical synthesis, $10 \mathrm{~mL}$ of TOA was added in a $50 \mathrm{~mL}$ three-neck flask and heated to $130{ }^{\circ} \mathrm{C}$ for 30 min under Ar atmosphere. After cooling to room temperature, $0.246 \mathrm{~g}$ of $\mathrm{CuOAc}$ and $0.556 \mathrm{~g}$ of TDPA were placed into the flask. The mixture was heated up to $180{ }^{\circ} \mathrm{C}$ and 
maintained at this temperature for 30 minutes. Afterward, the reaction temperature was further increased to $270{ }^{\circ} \mathrm{C}$ and kept for another 30 minutes, before cooling down to ambient temperature. $\mathrm{Cu}$ NPs were purified by multiple precipitation/re-dispersion steps using methanol as a non-solvent and hexane as solvent.

Cobalt-copper nanoparticles: Co-Cu NPs were produced by a one-pot two-step procedure. First, Co NPs were synthesized following the above procedure. In a second step, inside the 250 $\mathrm{mL}$ three-neck flask containing the Co NPs, different volumes of stock solution of $\mathrm{Cu}^{+}$ions in OLA $(0.25 \mathrm{M})$ were added at room temperature $\left(6.25 \mathrm{~mL}\right.$ to produce $\mathrm{Co}_{0.6}-\mathrm{Cu}_{0.4} \mathrm{NPs}$ and 12.5 $\mathrm{mL}$ to get $\mathrm{Co}_{0.3}-\mathrm{Cu}_{0.7} \mathrm{NPs}$ ). Then the mixture was heated up to $180{ }^{\circ} \mathrm{C}$ and maintained at this temperature for $30 \mathrm{~min}$. Afterward, the solution was cooled down and NPs were purified by three hexane/isopropanol re-dispersion/precipitation cycles. NPs nomenclature $\left(\mathrm{Co}_{\mathrm{x}}-\mathrm{Cu}_{\mathrm{y}}\right)$ indicates the $\mathrm{Co} / \mathrm{Cu}$ molar relation $([\mathrm{Co} / \mathrm{Cu}]=\mathrm{x} / \mathrm{y})$.

SiO $_{2}$-supported nanoparticles: Metal NPs were incorporated via capillary inclusion to a mesoporous hydrophobic $\mathrm{SiO}_{2}$ support with a surface area of $191 \mathrm{~m}^{2} / \mathrm{g}$ and an average pore size of $21 \mathrm{~nm}$ (AEROSIL R-9200 hydrophobic silica). ${ }^{28,45}$ In a typical preparation, $2 \mathrm{~g}$ of $\mathrm{SiO}_{2}$ were added to a hexane solution containing $200 \mathrm{mg}$ of NPs ( $150 \mathrm{mg}$ NPs after ligand removal). The slurry was sonicated for $2 \mathrm{~h}$ at room temperature to facilitate the introduction of NPs within the silica pores. After that, hexane was evaporated under vacuum. Before catalyst characterization and catalytic test, the nanopowder was annealed at $350^{\circ} \mathrm{C}$ for $4 \mathrm{~h}$ in air flow to remove organics.

Materials characterization: X-ray diffraction (XRD) patterns were obtained on a Bruker D8 automated diffractometer, equipped with a primary monochromator and a LynxEye detector and using $\mathrm{Cu} \mathrm{K \alpha}$ radiation ( $\lambda=1.5406 \AA$ ). The instrument resolution was $0.05^{\circ}$ in $2 \theta$, the studied range was between $35-55^{\circ}$ and the acquisition time for each sample was set to $2 \mathrm{~h} 20 \mathrm{~min}$. Metal 
contents were determined using optical emission spectroscopy by means of inductively coupled plasma (ICP) on a Perkin Elmer Optima 3200 RL system. The specific surface area of the materials was determined by $\mathrm{N}_{2}$ adsorption at $77 \mathrm{~K}$ using a Tristar II 3020 Micromeritics system. Thermogravimetric analyses (TGA) were performed in the temperature range of $30-700{ }^{\circ} \mathrm{C}$ at a heating rate of $5{ }^{\circ} \mathrm{C} \min ^{-1}$ under air using a Perkin Elmer TGA4000. Transmission electron microscopy (TEM) and high resolution TEM (HRTEM) micrographs were obtained using a Carl ZEISS LIBRA 120 microscope operated at $120 \mathrm{keV}$ and a field emission gun (FEG) FEI Tecnai F20 microscope operated at $200 \mathrm{keV}$, respectively. Scanning TEM (STEM)-electron energy-loss spectroscopy (EELS) and STEM-energy dispersive X-ray spectroscopy (EDX) analyses are conducted on the Tecnai microscope equipped with high angle annular dark field (HAADF) and EDX detectors and a Quantum Gatan Image Filter (GIF). EDX analyses were performed with an EDAX Octane T Ultra W /Apollo XLT2 SDD. The software used to interpret the images was the FEI TEM Imaging \& Analysis (TIA).

Hydrogen temperature-programmed reduction (TPR) was performed using a Micromeritics AutoChem HP 2950 chemisorption analyzer. $50 \mathrm{mg}$ of sample were pretreated at $90{ }^{\circ} \mathrm{C}$ for 30 min under flowing $\mathrm{He}(50 \mathrm{~mL} / \mathrm{min})$. After cooling to room temperature, the samples were reduced in a flow of $12 \mathrm{vol} \% \mathrm{H}_{2} / \mathrm{Ar}(50 \mathrm{~mL} / \mathrm{min})$ and temperature was linearly increased at a rate of $10^{\circ} \mathrm{C} / \min$ up to $800{ }^{\circ} \mathrm{C}$.

The $\mathrm{Cu}^{\circ}$ surface area was determined by dissociative $\mathrm{N}_{2} \mathrm{O}$ adsorption using a Micromeritics AutoChem HP 2950 chemisorption analyzer. $50 \mathrm{mg}$ of each sample were pretreated at $90{ }^{\circ} \mathrm{C}$ for $30 \mathrm{~min}$ under flowing $\mathrm{He}(50 \mathrm{~mL} / \mathrm{min})$. After cooling to room temperature, samples were reduced in a flow of $12 \mathrm{vol} \% \mathrm{H}_{2} / \mathrm{Ar}(50 \mathrm{~mL} / \mathrm{min})$ and temperature was linearly increased at a rate of $10{ }^{\circ} \mathrm{C} / \mathrm{min}$ up to $350{ }^{\circ} \mathrm{C}$ at 30 bar. Again after cooling at $35{ }^{\circ} \mathrm{C}$, samples were oxidized in a 
flow of $6 \% \mathrm{~N}_{2} \mathrm{O} / \mathrm{He}(10 \mathrm{~mL} / \mathrm{min})$ for 1 hour. Finally, samples were flushed with He to remove the oxidant and cooled to room temperature to start another TPR run. The exposed $\mathrm{Cu}$ surface area $\left(\mathrm{S}_{\mathrm{Cu}}\right)$ in the reduced catalysts was calculated on the basis of $\mathrm{Cu} / \mathrm{N}_{2} \mathrm{O}=2$ titration stoichiometry and a surface atomic density of $1.4 \times 10^{19} \mathrm{Cu}$ atoms per $\mathrm{m}^{2}$.

Catalytic behavior: Catalytic tests were carried out in a Microactivity-Reference unit (PID Eng\&TECH) in the temperature range $280-350{ }^{\circ} \mathrm{C}$ at 30 bar. $100 \mathrm{mg}$ of catalyst was mixed with inactive $\mathrm{SiC}$ (Prolabo, $0.5 \mathrm{~mm}$ ) and placed in a tubular fixed-bed reactor $(305 \mathrm{~mm}$ long, $9 \mathrm{~mm}$ i.d., 316-L stainless steel) up to a catalytic bed volume of $1 \mathrm{~mL}$. The temperature was measured by a thermocouple in direct contact with the catalytic bed. Before the reaction, the catalyst was in-situ reduced using a mixture of $12 \% \mathrm{vol} / \mathrm{vol} \mathrm{H}_{2} / \mathrm{Ar}$, temperature and pressure were linearly increased at $350{ }^{\circ} \mathrm{C}$ and 30 bar for $1 \mathrm{~h}$ and then kept at these conditions for another 30 minutes. Thereafter, the pressure was kept at 30 bar and the temperature was decreased to $280{ }^{\circ} \mathrm{C}$. Then the catalyst was exposed to a reactant gas mixture of $\mathrm{CO}_{2} / \mathrm{H}_{2}=1 / 3$ balanced with $20 \%$ of $\mathrm{N}_{2}$, as an internal standard, under a gas hourly space velocity (GHSV) of $3000 \mathrm{~h}^{-1}$. After a period of $4 \mathrm{~h}$ at $280{ }^{\circ} \mathrm{C}$, the reaction temperature was consecutively increased to $300{ }^{\circ} \mathrm{C}, 320{ }^{\circ} \mathrm{C}, 340{ }^{\circ} \mathrm{C}$ and $350{ }^{\circ} \mathrm{C}$ and maintained at each temperature for $4 \mathrm{~h}$. After each temperature change, the system was stabilized for $1 \mathrm{~h}$ and then the corresponding initial activity at a given temperature was determined. The products were analyzed on-line with a GC system (Varian 450-GC) equipped with a methanizer, TCD and FID detectors. $\mathrm{CO}_{2}$ conversion $\left(X_{\mathrm{CO}_{2}}\right)$ and the selectivity $\left(\mathrm{S}_{\mathrm{i}}\right)$ for each product (excluding $\mathrm{H}_{2} \mathrm{O}$ ) were calculated according to:

$$
X_{\mathrm{CO}_{2}}=\frac{\sum n_{i} P_{i}}{\left[C O_{2}\right]+\sum n_{i} P_{i}}
$$




$$
S_{i}=\frac{n_{i} P_{i}}{\sum n_{i} P_{i}}
$$

where $P_{i}$ and $n_{i}$ are the molar concentration and the number of carbon atoms of a specific product in the outlet gas, and $\left[\mathrm{CO}_{2}\right]$ is the $\mathrm{CO}_{2}$ molar concentration in the outlet gas. The relative selectivities of the catalysts towards the formation of hydrogenated products were calculated as $\mathrm{S}_{\mathrm{i}}$, but excluding $\mathrm{CO}$.

\section{RESULTS AND DISCUSSION}

Co-Cu NPs were produced by a one-pot two-step procedure. First, Co NPs were obtained by $\mathrm{Co}(\mathrm{CO})_{8}$ decomposition in the presence of TOPO and OLA at $180{ }^{\circ} \mathrm{C}$. After 10 min reaction, the solution was cooled down to room temperature and spherical Co NPs with an average size of 10 nm were obtained (Figure 1a). Then, $\mathrm{Cu}^{+}$ions were added to the Co NPs solution, and the mixture was heated up again to $180^{\circ} \mathrm{C}$. After 30 min reaction, slightly larger spherical NPs were obtained (Figure 1c). HRTEM micrographs showed the presence of Moiré fringes in the final Co-Cu NPs, pointing toward the superposition of two crystalline structures (Figure 1d). In the shell, the (011) and (111) planes of cuprite $\mathrm{Cu}_{2} \mathrm{O}$ with $2.44 \AA$ and $2.98 \AA$ distances, could be evidenced. EELS elemental maps revealed the final $\mathrm{Co}-\mathrm{Cu}$ NPs to be composed by a Co core and a partially oxidized $\mathrm{Cu}$ shell (Figure 1e), although a minor alloying cannot be discarded. The shell oxidation was associated with the NPs interaction with air during purification and during the preparation and transportation of TEM grids.

The Co core clearly shrank with the $\mathrm{Cu}^{+}$introduction, up to the point that when an excess amount of $\mathrm{Cu}^{+}$ions was introduced, $\mathrm{Co}$ was totally dissolved and pure $\mathrm{Cu}$ NPs were obtained. On the other hand, the injection of the $\mathrm{Cu}$ precursor in the exact same reaction conditions but in 
the absence of Co NPs, did not result in the formation of $\mathrm{Cu}$ NPs. These experimental facts evidenced that the $\mathrm{Cu}$ shell grew by the galvanic replacement of $\mathrm{Co}$ by $\mathrm{Cu}^{+}$ions in solution. ${ }^{46}$ This replacement was driven by the larger reduction potential of $\mathrm{Cu}^{+}$compared with $\mathrm{Co}^{2+}$ (at 25 ${ }^{\circ} \mathrm{C}$ and $\left.1 \mathrm{~atm}, E^{o}\left(\mathrm{Co}^{2+} / \mathrm{Co}\right)=-0.28 \mathrm{~V} ; E^{o}\left(\mathrm{Cu}^{+} / \mathrm{Cu}\right)=0.52 \mathrm{~V}\right)$. While galvanic replacement generally results in the formation of porous structures, the relatively high reaction temperatures used here $\left(180{ }^{\circ} \mathrm{C}\right)$ could allow the formed vacancies to diffuse to the surface, thus finally resulting in solid NPs. Because oxidation of each Co atom required the reduction and incorporation of two $\mathrm{Cu}^{+}$ions, increasingly larger NPs were obtained when increasing the Cu-toCo ratio. Such a synthetic strategy allowed to carefully adjust the metal composition of the final NPs and to produce $\mathrm{Co}-\mathrm{Cu} \mathrm{NPs}$ with the full range of $\mathrm{Cu}$ content by introducing the required precise amounts of copper ions..

Owing to the core-shell nature of the $\mathrm{Co}-\mathrm{Cu}$ NPs produced by the galvanic replacement strategy, we refer to them using the nomenclature: $\mathrm{Co}_{\mathrm{x}} @ \mathrm{Cu}_{1-\mathrm{x}}$, where $\mathrm{x}$ and $\mathrm{x}-1$ respectively denote the $\mathrm{Co}$ and $\mathrm{Cu}$ atomic ratio within the NP. We will maintain this nomenclature even after thermal treatment of the NPs in oxidizing or reducing atmospheres, which, as detailed below, clearly change the NP composition and phase distribution.

As a reference for the chemical, structural and functional characterization of the Co@Cu NPs, $10 \mathrm{~nm}$ Co NPs were also prepared by the same procedure $\left(1^{\text {st }}\right.$ step) and $10 \mathrm{~nm}$ spherical Cu NPs were prepared following Yang et al.'s procedure (Figure 1b). ${ }^{44}$ 

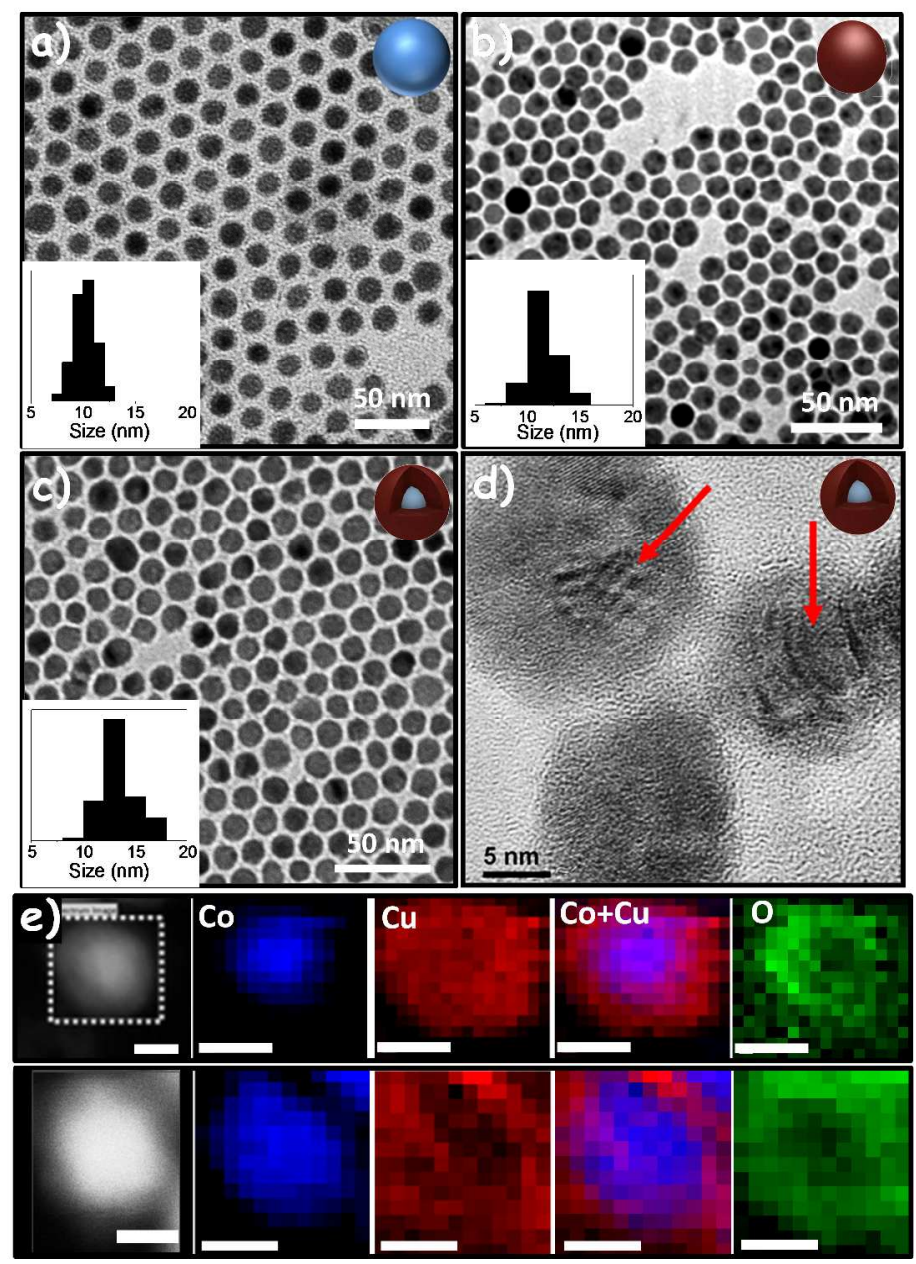

Figure 1. a)-c) TEM micrographs and size histograms (insets) of the $\mathrm{Co}$ (a), $\mathrm{Cu}$ (b) and $\mathrm{Co}_{0.6} @ \mathrm{Cu}_{0.4}$ (c) NPs. d) HRTEM micrograph of Co@Cu NPs. e) Two examples of HAADF (Zcontrast) images and $\mathrm{Co}, \mathrm{Cu}$ and $\mathrm{O}$ EELS compositional maps of $\mathrm{Co}_{0.6} @ \mathrm{Cu}_{0.4}$ NPs. Scale bars correspond to $5 \mathrm{~nm}$.

Figure 2 shows the XRD patterns of $\mathrm{Co}, \mathrm{Cu}$ and two $\mathrm{Co} @ \mathrm{Cu}$ samples with different $\mathrm{Co} / \mathrm{Cu}$ molar ratio: $\mathrm{Co}_{0.6} @ \mathrm{Cu}_{0.4}$ and $\mathrm{Co}_{0.3} @ \mathrm{Cu}_{0.7}$. $\mathrm{Co}$ and $\mathrm{Cu}$ NPs crystallized in the $\varepsilon-\mathrm{Co}$ and face centered cubic (fcc, JCPDS 89-2838) phases, respectively. ${ }^{47}$ However, Co@Cu NPs did not display the $\varepsilon$-Co phase, but showed a XRD pattern that resembled a fcc phase with lattice parameters in between those of $\mathrm{Co}$ and $\mathrm{Cu}$ fcc phases. We speculate that the metastable $\varepsilon$-Co 
phase transformed to the stable $\mathrm{Co}_{\mathrm{fcc}}$ during the additional 30 min treatment at $180{ }^{\circ} \mathrm{C}$ used to grow the $\mathrm{Cu}$ shell. A slight $\mathrm{Co}-\mathrm{Cu}$ alloying could help in this direction, although the solubility of the two metals is very low in the temperature range here considered. ${ }^{28,42,48-50}$

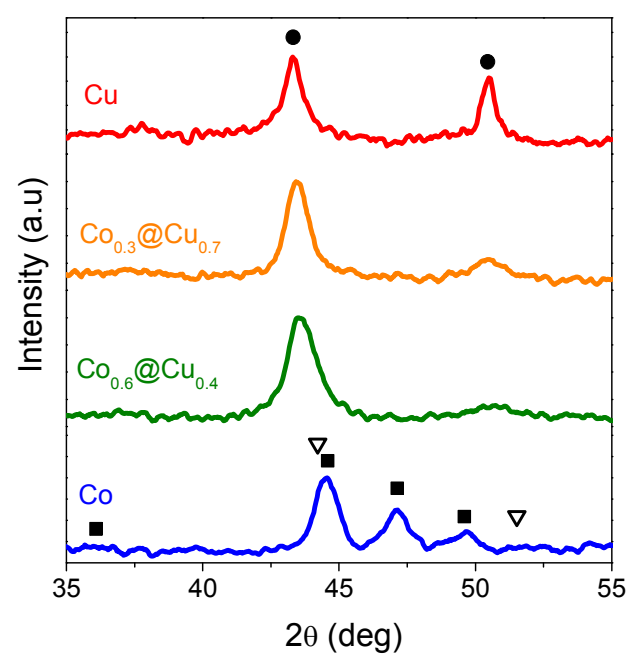

Figure 2. XRD patterns of $\mathrm{Co}, \mathrm{Co}_{0.6} @ \mathrm{Cu}_{0.4}, \mathrm{Co}_{0.3} @ \mathrm{Cu}_{0.7}$ and $\mathrm{Cu}$ unsupported nanoparticles. Peaks corresponding to $\mathbf{\varepsilon}-\mathrm{Co} ;{ }^{47} \nabla \mathrm{Co}$ fcc (JCPDS 15-0806); and $\bullet \mathrm{Cu}$ fcc (JCPDS 89-2838) are marked as a reference.

Five model catalysts were prepared by capillary inclusion of colloidal NPs $(7 \%$ wt) into mesoporous hydrophobic $\mathrm{SiO}_{2}$ : i) $\mathrm{Co} / \mathrm{SiO}_{2}$; ii) $\mathrm{Cu} / \mathrm{SiO}_{2}$; iii) $\mathrm{Co} / \mathrm{SiO}_{2}+\mathrm{Cu} / \mathrm{SiO}_{2}$ physical mixture (50\%wt); iv) $\mathrm{Co}_{0.6} @ \mathrm{Cu}_{0.4} / \mathrm{SiO}_{2}$; and v) $\mathrm{Co}_{0.3} @ \mathrm{Cu}_{0.7} / \mathrm{SiO}_{2}$. Organic capping agents from the NP surface were thermally decomposed in air for $4 \mathrm{~h}$ at $350{ }^{\circ} \mathrm{C}$. This temperature was selected on the basis of TGA (supporting information, SI, Figure SI1). The composition of the final catalysts, calculated by ICP, is displayed in Table SI1.

Figure 3a shows a low magnification HAADF STEM micrograph of the $\mathrm{Co}_{0.3} @ \mathrm{Cu}_{0.7} / \mathrm{SiO}_{2}$ sample after thermal treatment in air. High contrast $\mathrm{Co}_{0.3} @ \mathrm{Cu}_{0.7} \mathrm{NPs}$ can be identified within the lower contrast $\mathrm{SiO}_{2}$ matrix. While most NPs were found individually distributed over the $\mathrm{SiO}_{2}$ 
surface, some aggregation was also observed. Because of this slight aggregation, we discarded the $\mathrm{Co}+\mathrm{Cu} / \mathrm{SiO}_{2}$ catalyst, with a mixture of $\mathrm{Co}$ and $\mathrm{Cu}$ NPs simultaneously incorporated in the same support, as a reference material, as it contained an un-controlled combination of independent $\mathrm{Cu}$ and $\mathrm{Co}$ NPs and aggregates of $\mathrm{Co}+\mathrm{Cu}$ NPs.

HRTEM analysis (Figures 3b, SI2, SI3) showed the oxidized core-shell NPs to be polycrystalline. Power spectrum analysis revealed the presence of the fcc $\mathrm{Co}_{3} \mathrm{O}_{4}$ and/or a $\mathrm{Co}_{3}$ ${ }_{x} \mathrm{Cu}_{\mathrm{x}} \mathrm{O}_{4}$ phase across the NP. Spinel cubic phase has a general formula $\mathrm{AB}_{2} \mathrm{O}_{4}$, where A and $\mathrm{B}$ correspond to tetrahedral and octahedral cation sites, respectively, in a cubic close packing of oxygen. $\mathrm{Cu}^{2+}$ may substitute $\mathrm{Co}^{3+}$ at octahedral sites and result in the $\mathrm{Co}_{3-\mathrm{x}} \mathrm{Cu}_{\mathrm{x}} \mathrm{O}_{4}$ spinel phase. While $\mathrm{Co}_{3} \mathrm{O}_{4}$ and $\mathrm{Co}_{3-\mathrm{x}} \mathrm{Cu}_{\mathrm{x}} \mathrm{O}_{4}$ phases could not be differentiated due to their small lattice parameter differences, the random distribution of phases and metals within each NP already pointed toward the inter-diffusion of the two elements, $\mathrm{Co}$ and $\mathrm{Cu}$, during oxidation at $350{ }^{\circ} \mathrm{C}$.
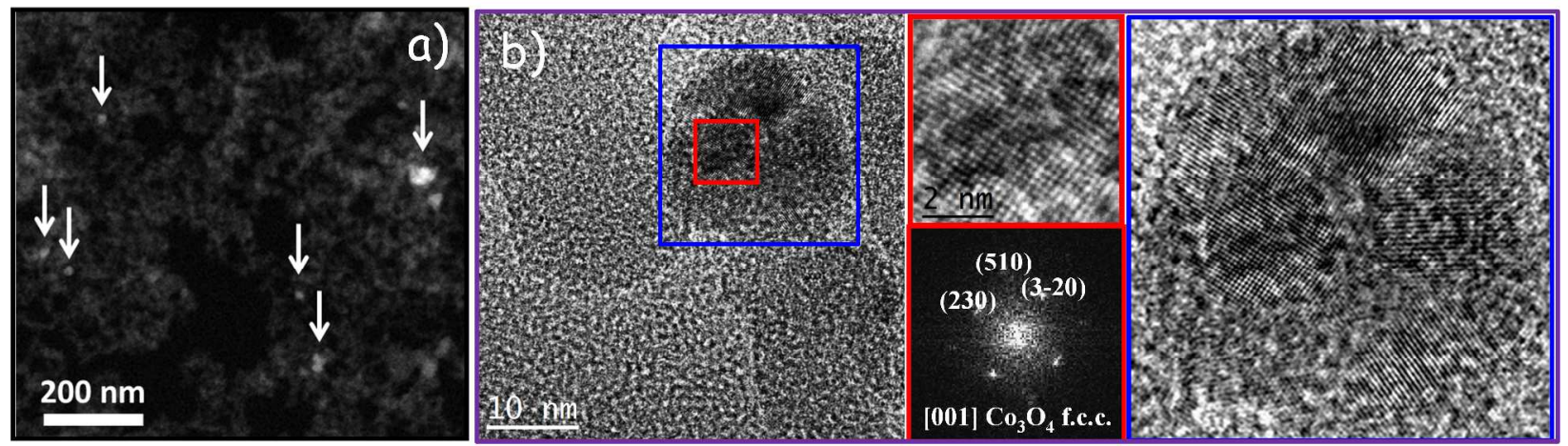

Figure 3. a) Low magnification HAADF-STEM micrograph of $\mathrm{Co}_{0.3} @ \mathrm{Cu}_{0.7} / \mathrm{SiO}_{2}$. Arrows point at the higher contrast $\mathrm{Co} @ \mathrm{Cu}$ NPs; b) HRTEM micrograph showing a polycrystalline oxidized $\mathrm{Co}_{0.3} @ \mathrm{Cu}_{0.7}$ NP. A detail of the blue region clearly shows the NP polycrystallinity. A detail of the red squared region and its corresponding power spectrum shows a $\mathrm{Co}_{3} \mathrm{O}_{4}$ or $\mathrm{Co}_{3-\mathrm{x}} \mathrm{Cu}_{\mathrm{x}} \mathrm{O}_{4}$ fcc phase $($ space group $=\mathrm{Fd} 3-\mathrm{ms}$ ) with lattice parameter $\mathrm{a}=0.814 \mathrm{~nm}$ and visualized along its [001] zone axis. 
The nature of the oxide phases formed after oxidation was further analyzed by XRD (Figure 4). In the monometallic catalysts, $\mathrm{Co} / \mathrm{SiO}_{2}$ and $\mathrm{Cu} / \mathrm{SiO}_{2}$, main diffraction peaks of $\mathrm{Co}_{3} \mathrm{O}_{4}$ spinel phase (JCPDS 42-1467) and $\mathrm{CuO}$ monoclinic phase (JCPDS 05-0661) were identified, respectively. The $\mathrm{Co} / \mathrm{SiO}_{2}+\mathrm{Cu} / \mathrm{SiO}_{2}$ catalyst showed the peaks corresponding to the same oxide phases detected in monometallic samples. In the $\mathrm{Co} @ \mathrm{Cu} / \mathrm{SiO}_{2}$ catalysts, XRD peaks corresponding to the $\mathrm{CuO}$ monoclinic phase were clearly identified. Furthermore, diffraction peaks at $31.2^{\circ}, 36.7^{\circ}$ and $44.7^{\circ}$ could be assigned to the presence of $\mathrm{Co}_{3} \mathrm{O}_{4}$ and $/ \mathrm{or}^{\mathrm{Co}_{3-\mathrm{x}}} \mathrm{Cu}_{\mathrm{x}} \mathrm{O}_{4}$ in spinel phase. From the ratio between the $\mathrm{CuO}$ and the $\mathrm{Co}_{3} \mathrm{O}_{4} \mathrm{XRD}$ peaks obtained from the $50 \%$ $\mathrm{Co} / \mathrm{SiO}_{2}+\mathrm{Cu} / \mathrm{SiO}_{2}$ sample and considering $50 \%$ of each $\mathrm{CuO}$ and $\mathrm{Co}_{3} \mathrm{O}_{4}$ in this material, we estimated the $\mathrm{Co}_{3-\mathrm{x}} \mathrm{Cu}_{\mathrm{x}} \mathrm{O}_{4}$ spinel phase could account for up to a $10 \%$ of the $\mathrm{Cu}$ atoms in the $\mathrm{Co}_{0.3} @ \mathrm{Cu}_{0.7} / \mathrm{SiO}_{2}$ and up to a $20 \%$ of the $\mathrm{Cu}$ in the $\mathrm{Co}_{0.6} @ \mathrm{Cu}_{0.4} / \mathrm{SiO}_{2}$.

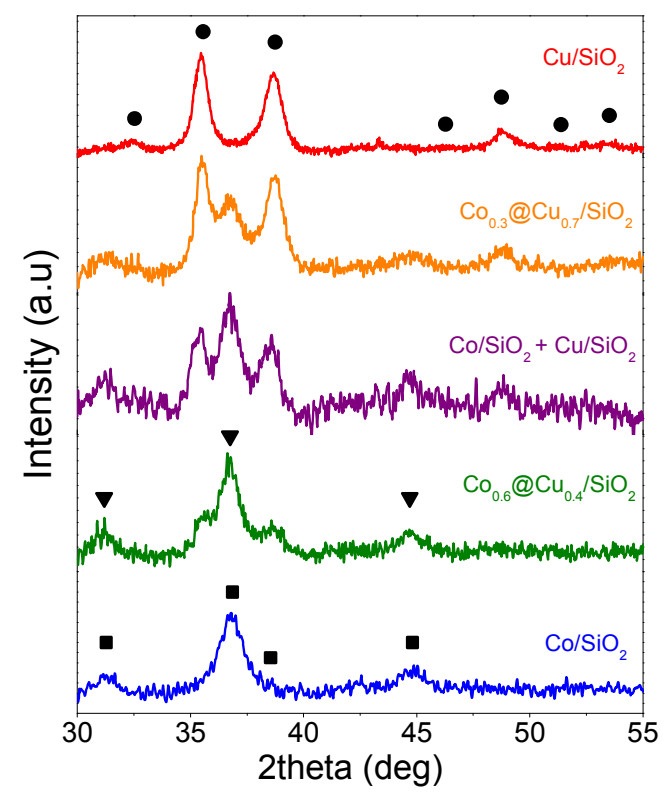

Figure 4. $\mathrm{XRD}$ patterns of the $\mathrm{Co} / \mathrm{SiO}_{2}, \mathrm{Cu} / \mathrm{SiO}_{2}, \mathrm{Co} / \mathrm{SiO}_{2}+\mathrm{Cu} / \mathrm{SiO}_{2}, \mathrm{Co}_{0.6} @ \mathrm{Cu}_{0.4} / \mathrm{SiO}_{2}$ and $\mathrm{Co}_{0.3} @ \mathrm{Cu}_{0.7} / \mathrm{SiO}_{2}$ catalysts after oxidation at $350{ }^{\circ} \mathrm{C}$. The peaks corresponding to $\mathrm{Co}_{3} \mathrm{O}_{4}$ (JCPDS 42-1467), $\boldsymbol{\nabla} \mathrm{Co}_{2} \mathrm{CuO}_{4}(\mathrm{JCPDS} 37-0878)$ and $\bullet \mathrm{CuO}$ (JCPDS 05-0661) are marked as a reference. 
Figure 5 shows the TPR profiles measured from the different catalysts. The $\mathrm{Co} / \mathrm{SiO}_{2}$ catalyst was characterized by a two-step reduction profile with maxima of hydrogen consumption at 275 ${ }^{\circ} \mathrm{C}$ and $311{ }^{\circ} \mathrm{C}: \mathrm{Co}_{3} \mathrm{O}_{4} \rightarrow \mathrm{CoO} \rightarrow$ Co. ${ }^{51-53}$ The reduction profile of $\mathrm{Cu} / \mathrm{SiO}_{2}$ was essentially characterized by a broad peak at lower temperatures than $\mathrm{CoO}$, with a maximum of hydrogen consumption at $210{ }^{\circ} \mathrm{C} .{ }^{53,54}$ The TPR profile of the $\mathrm{Co} / \mathrm{SiO}_{2}+\mathrm{Cu} / \mathrm{SiO}_{2}$ sample showed the peaks associated to the independent reduction of pure oxides, $\mathrm{Co}_{3} \mathrm{O}_{4}$ and $\mathrm{CuO}$, what suggested no interaction or promotional effect between the two elements. On the other hand, $\mathrm{Co} @ \mathrm{Cu} / \mathrm{SiO} 2$ catalysts were characterized by a unique reduction peak at temperatures in between those of $\mathrm{Co} / \mathrm{SiO}_{2}$ and $\mathrm{Cu} / \mathrm{SiO}_{2}$ catalysts, which shifted toward lower temperatures when increasing the $\mathrm{Cu}$ content in the NP. This confirmed a synergistic effect in the reduction of both species, where $\mathrm{Cu}$ probably promoted the $\mathrm{Co}^{\mathrm{n}+}$ reduction, and suggested an intimate contact of the cobalt and copper species and a good sample homogeneity. ${ }^{53-56}$

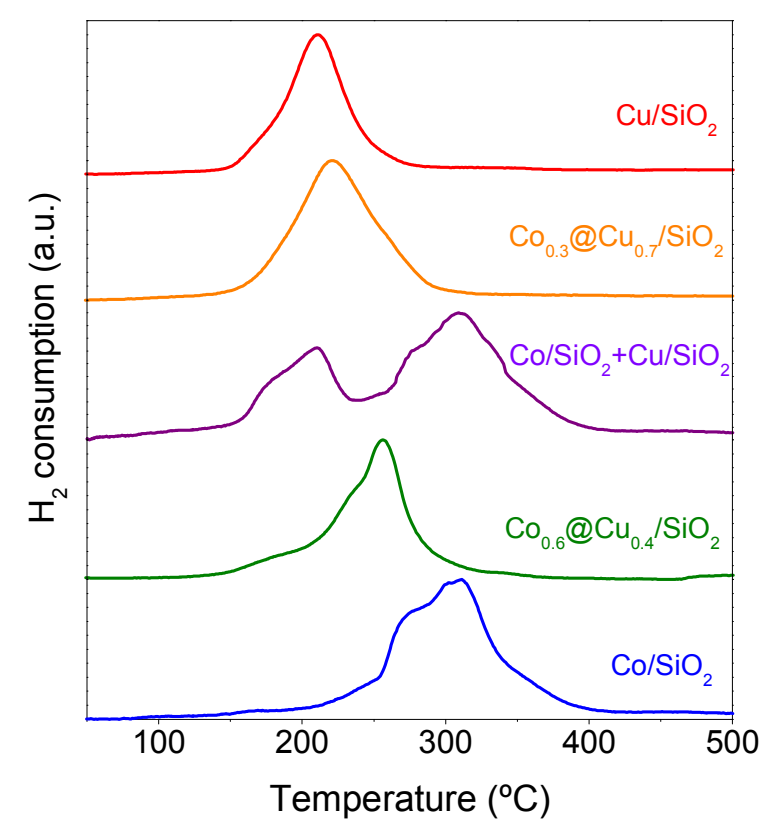

Figure 5. $\mathrm{H}_{2}$ temperature programmed reduction profiles of $\mathrm{Co} / \mathrm{SiO}_{2}, \mathrm{Cu} / \mathrm{SiO}_{2}$, $\mathrm{Co} / \mathrm{SiO}_{2}+\mathrm{Cu} / \mathrm{SiO}_{2}, \mathrm{Co}_{0.6} @ \mathrm{Cu}_{0.4} / \mathrm{SiO}_{2}$ and $\mathrm{Co}_{0.3} @ \mathrm{Cu}_{0.7} / \mathrm{SiO}_{2}$ catalysts. 
To further study the structural and chemical evolution of the $\mathrm{Co} @ \mathrm{Cu}$ NPs during oxidation and reduction treatments, TEM analysis of the NPs supported on a silicon nitride grid was carried out after each thermal treatment. Figure 6 shows TEM micrographs of the exact same $\mathrm{Co}_{0.3} @ \mathrm{Cu}_{0.7}$ NPs just after their preparation (Figure 6a), after oxidation at $350{ }^{\circ} \mathrm{C}$ for 4 hours in air (Figure 6b) and after reduction at $350{ }^{\circ} \mathrm{C}$ and 30 bar in a $12 \% \mathrm{H}_{2}$-Ar (Figure 6c). After the thermal treatment in air, slightly larger polycrystalline NPs with no clear contrast between a hypothetical core and a shell were identified. Some voids were observed within the NPs after oxidation, which we assigned to the nanoscale Kirkendall effect and pointed toward a faster diffusion of Co and/or $\mathrm{Cu}$ than oxygen through the growing metal oxide shell (Figure SI4). ${ }^{57-60}$

After the reduction treatment, NPs shrank and a core-shell structure was recovered. HRTEM and EDS analysis showed the reduced NPs to be formed by a polycrystalline CoO shell and a metallic $\mathrm{Cu}$ core (Figure 7, SI5-SI7). Taking into account the hydrogen consumed from TPR results, we believe that the cobalt oxide shell was completely reduced during the $\mathrm{H}_{2}$ treatment, but it oxidized when exposed to air before TEM analysis.
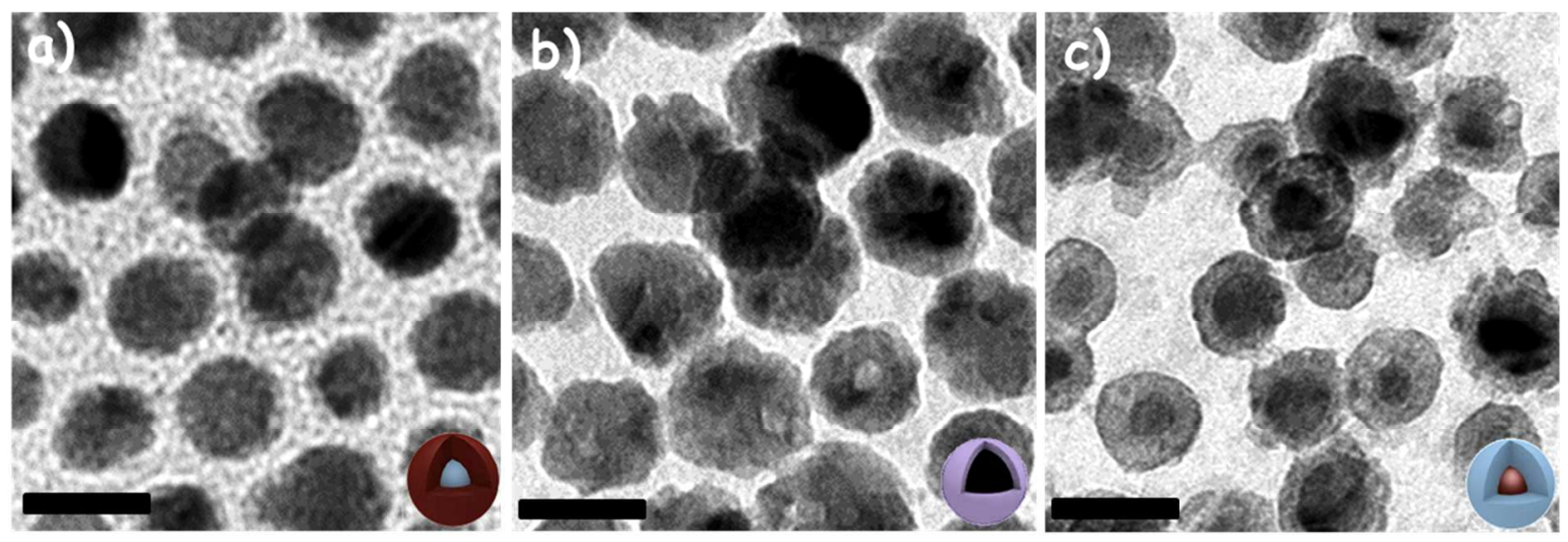

Figure 6. TEM micrographs from the same $\mathrm{Co}_{0.3} @ \mathrm{Cu}_{0.7} \mathrm{NPs}$ supported on a $\mathrm{SiN}_{\mathrm{x}} \mathrm{TEM}$ grid after different treatments: a) initial $\left.\mathrm{Co}_{0.3} @ \mathrm{Cu}_{0.7} \mathrm{NPs}, \mathrm{b}\right)$ after thermal treatment in air at $350{ }^{\circ} \mathrm{C}$ during $4 \mathrm{~h}$; c) after reduction in $12 \% \mathrm{H}_{2}$-Ar at $350{ }^{\circ} \mathrm{C}$ at 30 bar. Scale bar corresponds to $20 \mathrm{~nm}$. 

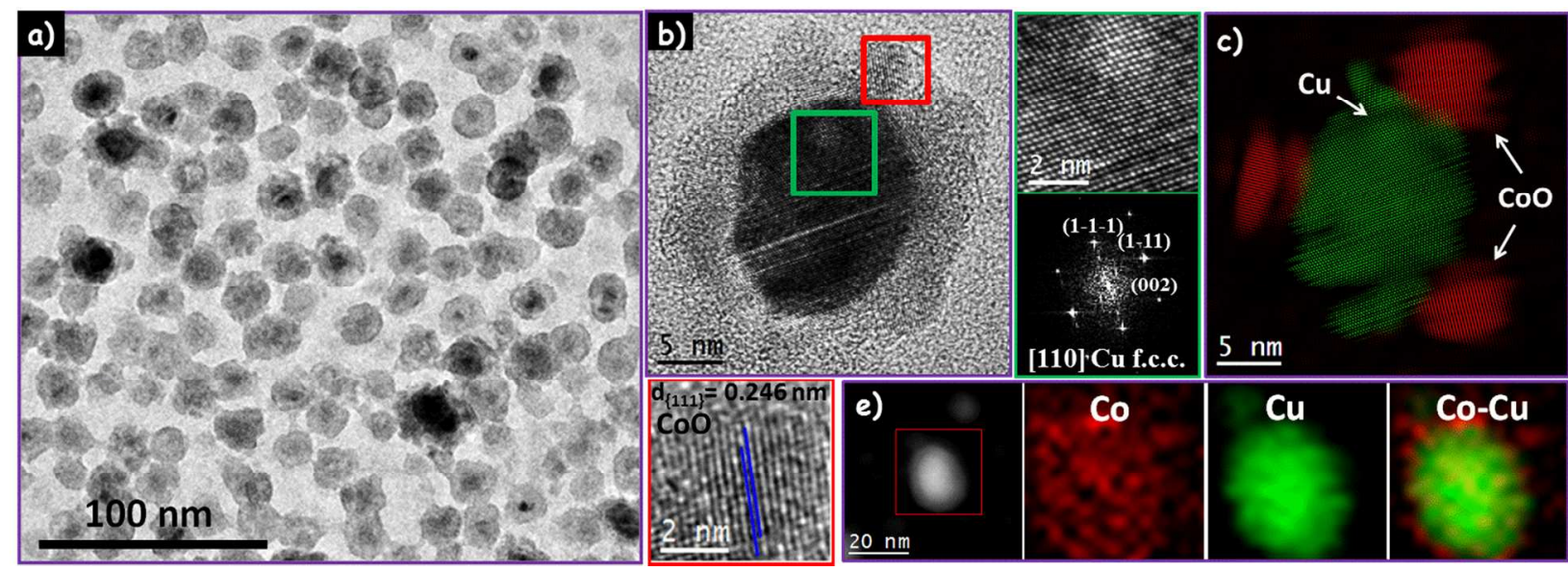

Figure 7. a) TEM micrographs of $\mathrm{Co}_{0.3} @ \mathrm{Cu}_{0.7} \mathrm{NPs}$ oxidized in air at $350{ }^{\circ} \mathrm{C}$ during $4 \mathrm{~h}$ and reduced in $12 \% \mathrm{H}_{2}-\mathrm{Ar}$ at $350{ }^{\circ} \mathrm{C}$ at 30 bar; b) HRTEM micrograph of a reduced $\mathrm{Co}_{0.3} @ \mathrm{Cu}_{0.7}$ NPs with details of shell (red squared) and core (green squared) regions and corresponding power spectrum of the core. HRTEM is consistent with a metallic $\mathrm{Cu}$ core and a $\mathrm{CoO}$ shell. $\mathrm{C}$ ) Colorful crystallographic map of the same NP where green indicates the f.c.c. $\mathrm{Cu}$ phase and red indicates the f.c.c. $\mathrm{CoO}$ phase. e) EDX compositional maps of a $\mathrm{Co}_{0.3} @ \mathrm{Cu}_{0.7} \mathrm{NP}$ after the reduction process.

According to these experimental evidences, we hypothesize that during the oxidation treatment, the diffusion of cobalt through an initially formed $\mathrm{CuO}$ shell takes place, leaving a void within the particle. With the reduction treatment, metal copper collapsed to the center of the NP and Co remained at its surface. Upon exposure to air during TEM sample preparation and transportation, Co was oxidized into a thicker and lower contrast $\mathrm{CoO}$ shell than that of the initial Co@Cu NPs. This explains the different electron microscopy contrast between the asproduced Co@Cu NPs and the reduced ones. Notice finally that, in spite of the diffusion of the different components within each individual particle, resulting in an inversion of the core-shell structure, NPs supported on $\mathrm{SiN}_{\mathrm{x}}$ did not coalesce or aggregate. These results are slightly different from those obtained by Somorjai and collaborators, who studied the compositional re- 
organization of $\mathrm{Cu} @ \mathrm{Co}$ NPs, observing the surface segregation of $\mathrm{Cu}$ during oxidation, the surface segregation of $\mathrm{Co}$ during reduction, and the formation $\mathrm{Cu}-\mathrm{Co}$ dimers after the redox conditioning. $^{28}$

The specific $\mathrm{Cu}^{\circ}$ surface area in the reduced catalysts was estimated by adsorptive decomposition of nitrous oxide. ${ }^{61,62}$ We assumed the dissociation of nitrous oxide to take place only on the surface of copper according to the reaction: $2 \mathrm{Cu}_{(\mathrm{s})}+\mathrm{N}_{2} \mathrm{O} \rightarrow \mathrm{Cu}_{2} \mathrm{O}_{(\mathrm{s})}+\mathrm{N}_{2}$. The amount of $\mathrm{Cu}_{2} \mathrm{O}$ formed after $\mathrm{N}_{2} \mathrm{O}$ chemisorption was determined using TPR. While it was previously established that the optimum temperature range for $\mathrm{N}_{2} \mathrm{O}$ adsorption was $60-90{ }^{\circ} \mathrm{C},{ }^{61-63}$ our reference $\mathrm{Co} / \mathrm{SiO}_{2}$ sample was also oxidized by $\mathrm{N}_{2} \mathrm{O}$ in this temperature range. Therefore, to selectively estimate the $\mathrm{Cu}$ surface area, we reduced the adsorption temperature to $35^{\circ} \mathrm{C}$, where we measured an $\mathrm{N}_{2} \mathrm{O}$-related oxidation of the $\mathrm{Cu} / \mathrm{SiO}_{2}$ sample but not of the $\mathrm{Co} / \mathrm{SiO}_{2}$ catalyst. Even in this low temperature range, $\mathrm{Cu}$ surface areas were overestimated (table SI2). Nevertheless, they were systematically higher for catalyst with the following compositions $\mathrm{Cu} / \mathrm{SiO}_{2}>\mathrm{Co}_{0.3} @ \mathrm{Cu}_{0.7} / \mathrm{SiO}_{2}>\mathrm{Co}_{0.6} @ \mathrm{Cu}_{0.4} / \mathrm{SiO}_{2}>\mathrm{Co} / \mathrm{SiO}_{2}+\mathrm{Cu} / \mathrm{SiO}_{2}$. These results may indicate that in spite of the core-shell inversion, a significant part of the $\mathrm{Cu}$ surface areas were still accessible within $\mathrm{Co}_{0.6} @ \mathrm{Cu}_{0.4} / \mathrm{SiO}_{2}$ and $\mathrm{Co}_{0.3} @ \mathrm{Cu}_{0.7} / \mathrm{SiO}_{2}$ catalysts. This suggests that the Cobased shell was porous and permeable to $\mathrm{N}_{2} \mathrm{O}$ or that the surface composition of the $\mathrm{Co@Cu} \mathrm{NPs}$ after reduction was not pure $\mathrm{Co}$ but a $\mathrm{Co}-\mathrm{Cu}$ alloy which interacted with $\mathrm{N}_{2} \mathrm{O}$. However, $\mathrm{N}_{2} \mathrm{O}$ absorption results could be also explained by considering that the presence of a $\mathrm{Cu}$ core in direct contact with the Co shell was able to promote Co oxidation by $\mathrm{N}_{2} \mathrm{O}$, although independent Co NPs did not interact with $\mathrm{N}_{2} \mathrm{O}$ at $35^{\circ} \mathrm{C}$.

Figure 8 displays the total $\mathrm{CO}_{2}$ hydrogenation conversion at 30 bar and $3000 \mathrm{~h}^{-1}$ over $\mathrm{SiO}_{2^{-}}$ supported monometallic and bimetallic catalysts. Total conversions were much higher for the 
two reference catalysts containing independent Co NPs than for the pure $\mathrm{Cu}$-based catalyst and the $\mathrm{Co} @ \mathrm{Cu} / \mathrm{SiO}_{2}$ catalysts. Previous works demonstrated that too small Co NPs $(<10 \mathrm{~nm})$ showed lower activity in $\mathrm{CO}_{2}$ hydrogenation ${ }^{28,35-37}$ and $\mathrm{F}-\mathrm{T}^{12,36,39}$ reactions and attributed it to a higher susceptibility to oxidation ${ }^{11 \mathrm{~d}}$ and a related lower capability to dissociate $\mathrm{CO}^{39} \mathrm{We}$ associate the higher $\mathrm{CO}_{2}$ conversions of $\mathrm{Co} / \mathrm{SiO}_{2}$-containing catalysts to: i) the higher $\mathrm{CO}_{2}$ and $\mathrm{CO}$ dissociation rates on $\mathrm{Co}$ than $\mathrm{Cu} ;{ }^{64,65}$ ii) the larger size of the Co crystalline domains in the $\mathrm{Co} / \mathrm{SiO}_{2}$ catalysts compared with the $\mathrm{Co} @ \mathrm{Cu} / \mathrm{SiO}_{2}$ catalysts; iii) the lower $\mathrm{CO}_{2}$ hydrogenation activity of the Co shells in $\mathrm{Co} @ \mathrm{Cu} / \mathrm{SiO}_{2}$ catalysts, which could also be related to a higher oxidation susceptibility.

For all catalysts, conversion increased with temperature up to $340^{\circ} \mathrm{C}$. Above this temperature, catalysts containing Co NPs showed a clear decrease in conversion (Figure 8). This is related to a progressive loss of their capacity to produce hydrocarbons when heated at $340{ }^{\circ} \mathrm{C}$ and above under reaction conditions (Figures SI8 and SI9). On the other hand, the conversion of the $\mathrm{Cu} / \mathrm{SiO}_{2}$ and $\mathrm{Co} @ \mathrm{Cu} / \mathrm{SiO}_{2}$ catalysts was significantly more stable over time (Figures SI10-SI12).

$\mathrm{CO}, \mathrm{CH}_{4}, \mathrm{C}_{2} \mathrm{H}_{6}, \mathrm{C}_{2} \mathrm{H}_{4}, \mathrm{C}_{3} \mathrm{H}_{6}$, and traces of $\mathrm{CH}_{3} \mathrm{OH}$ were the products obtained from the $\mathrm{CO}_{2}$ hydrogenation reaction over all the catalysts. Nevertheless, each catalyst was characterized by significantly different selectivities to each of these products. The main $\mathrm{CO}_{2}$ hydrogenation product on $\mathrm{Co} / \mathrm{SiO}_{2}$ was $\mathrm{CH}_{4}$, with conversion selectivities up to a $70 \%$ (Figure 8a). This result is consistent with previous works showing that low space velocities and high pressures favored high selectivities to methane on groups 8,9 and 10 metals supported on $\mathrm{SiO}_{2} \cdot{ }^{66,67}$ Furthermore, Co is known to adsorb $\mathrm{CO}$ and $\mathrm{CO}_{2}$ dissociatively in the presence of $\mathrm{H}_{2}$, leading to the loss of oxygen as water and the production of oxygen free hydrocarbons. In this catalyst, $\mathrm{CO}$ selectivities were in the range between $20 \%$ and $40 \%$ and increased with temperature in the high 
temperature range measured as the reverse water gas-shift reaction (RWGS) reaction was favored: ${ }^{14,15,30}$

$$
\mathrm{CO}_{2(\mathrm{~g})}+\mathrm{H}_{2(\mathrm{~g})} \rightleftarrows \mathrm{CO}_{(\mathrm{g})}+\mathrm{H}_{2} \mathrm{O}_{(\mathrm{g})} \quad \Delta \mathrm{G}_{298 \mathrm{~K}}=28,6 \mathrm{KJ} / \mathrm{mol}
$$

The main reaction product of $\mathrm{CO}_{2}$ hydrogenation on $\mathrm{Cu} / \mathrm{SiO}_{2}$ catalyst was $\mathrm{CO}$, with selectivities up to $85 \%$ (Figure $8 \mathrm{~b}$ ). $\mathrm{CH}_{4}$ was a minor component in the product stream for this catalyst, with selectivities around $10 \%$. This is consistent with the molecular adsorption of $\mathrm{CO}_{2}$ and $\mathrm{CO}$ on $\mathrm{Cu}$ and their slow dissociation, what favors alcohol production when combined with the appropriate support. ${ }^{30,31-34,68-72}$
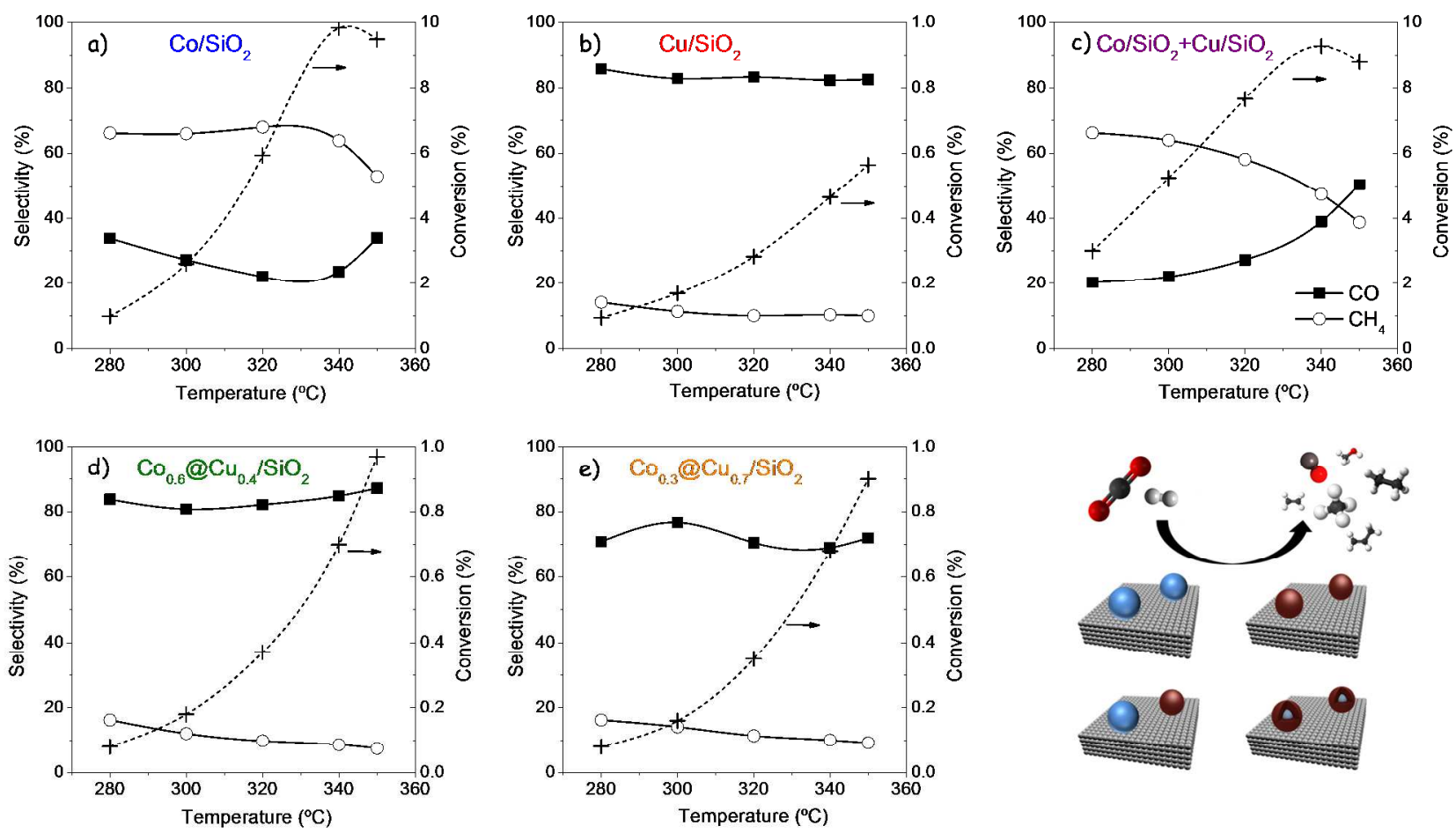

Figure 8. $\mathrm{CO}_{2}$ conversion and selectivities to $\mathrm{CO}$ and $\mathrm{CH}_{4}$ obtained from $\mathrm{Co} / \mathrm{SiO}_{2}(\mathrm{a}), \mathrm{Cu} / \mathrm{SiO}_{2}$ (b), $\mathrm{Co} / \mathrm{SiO}_{2}+\mathrm{Cu} / \mathrm{SiO}_{2}$ (c), $\mathrm{Co}_{0.6} @ \mathrm{Cu}_{0.4} / \mathrm{SiO}_{2}$ (d) and $\mathrm{Co}_{0.3} @ \mathrm{Cu}_{0.7} / \mathrm{SiO}_{2}$ (e) catalysts.

The catalytic performance of the physical mixture $\mathrm{Co} / \mathrm{SiO}_{2}+\mathrm{Cu} / \mathrm{SiO}_{2}$ was in between that of $\mathrm{Co} / \mathrm{SiO}_{2}$ and $\mathrm{Cu} / \mathrm{SiO}_{2}$, with $\mathrm{CH}_{4}$ selectivities from $65 \%$ to $40 \%$ and $\mathrm{CO}$ selectivities in the range 20-50\% (Figure 8c). On the contrary, $\mathrm{Co} @ \mathrm{Cu} / \mathrm{SiO}_{2}$ catalysts showed much higher tendencies to 
produce $\mathrm{CO}$, as the $\mathrm{Cu} / \mathrm{SiO}_{2}$ catalyst, and were characterized by relatively low methane selectivities (Figures 8d and 8e).

Aside from $\mathrm{CO}$ and $\mathrm{CH}_{4}, \mathrm{C} 2$ and $\mathrm{C} 3$ products were also produced with significant rates over monometallic and bimetallic catalysts. The production of higher hydrocarbons requires avoiding the formation of $\mathrm{CH}_{4}$, as it is the thermodynamically most stable product. To compare the selectivity towards the formation of the different hydrogenated products, figure 9 displays the relative selectivities (excluding $\mathrm{CO}$ ) of the different catalysts towards the formation of methane, ethane, ethylene, propene, and methanol.

The relative selectivities to $\mathrm{C} 2$ compounds, ethane and ethylene, were much higher for $\mathrm{Cu} / \mathrm{SiO}_{2}$ and $\mathrm{Co} @ \mathrm{Cu} / \mathrm{SiO}_{2}$ than for $\mathrm{Co} / \mathrm{SiO}_{2}$ and $\mathrm{Co} / \mathrm{SiO}_{2}+\mathrm{Cu} / \mathrm{SiO}_{2}$ catalysts. $40-65 \%$ relative selectivities toward de formation of $\mathrm{C} 2$ products were obtained for $\mathrm{Co} @ \mathrm{Cu} / \mathrm{SiO}_{2}$ catalysts above $300{ }^{\circ} \mathrm{C}$. Furthermore, propene was only detected on the bimetallic catalysts, with much higher selectivities for the $\mathrm{Co} @ \mathrm{Cu} / \mathrm{SiO}_{2}$ than for $\mathrm{Co} / \mathrm{SiO}_{2}+\mathrm{Cu} / \mathrm{SiO}_{2}$ catalysts. The higher relative selectivities of $\mathrm{Co} @ \mathrm{Cu} / \mathrm{SiO}_{2}$ catalysts to carbon chain growth confirmed the positive synergy between the two metals when combined within the same particle.

Methanol selectivities were very low for all catalysts (Figure 9). We associate this experimental fact to the need for a more suitable support than silica. ${ }^{72}$ It is generally accepted that $\mathrm{Cu}$ is the active phase for methanol formation. ${ }^{30,31-34,68-72}$ However the support plays an extremely important role, and oxide supports such as $\mathrm{ZnO}, \mathrm{ZrO}_{2}$ or $\mathrm{Al}_{2} \mathrm{O}_{3}$ have been found essential to promote the methanol formation. As expected, $\mathrm{Cu}$-containing catalyst showed much higher relative methanol selectivities than $\mathrm{Co} / \mathrm{SiO}_{2}$. Furthermore, $\mathrm{Co} @ \mathrm{Cu} / \mathrm{SiO}_{2}$ catalysts also showed relative selectivities to methanol well beyond those of $\mathrm{Co} / \mathrm{SiO}_{2}+\mathrm{Cu} / \mathrm{SiO}_{2}$ catalyst (Figure 9). 

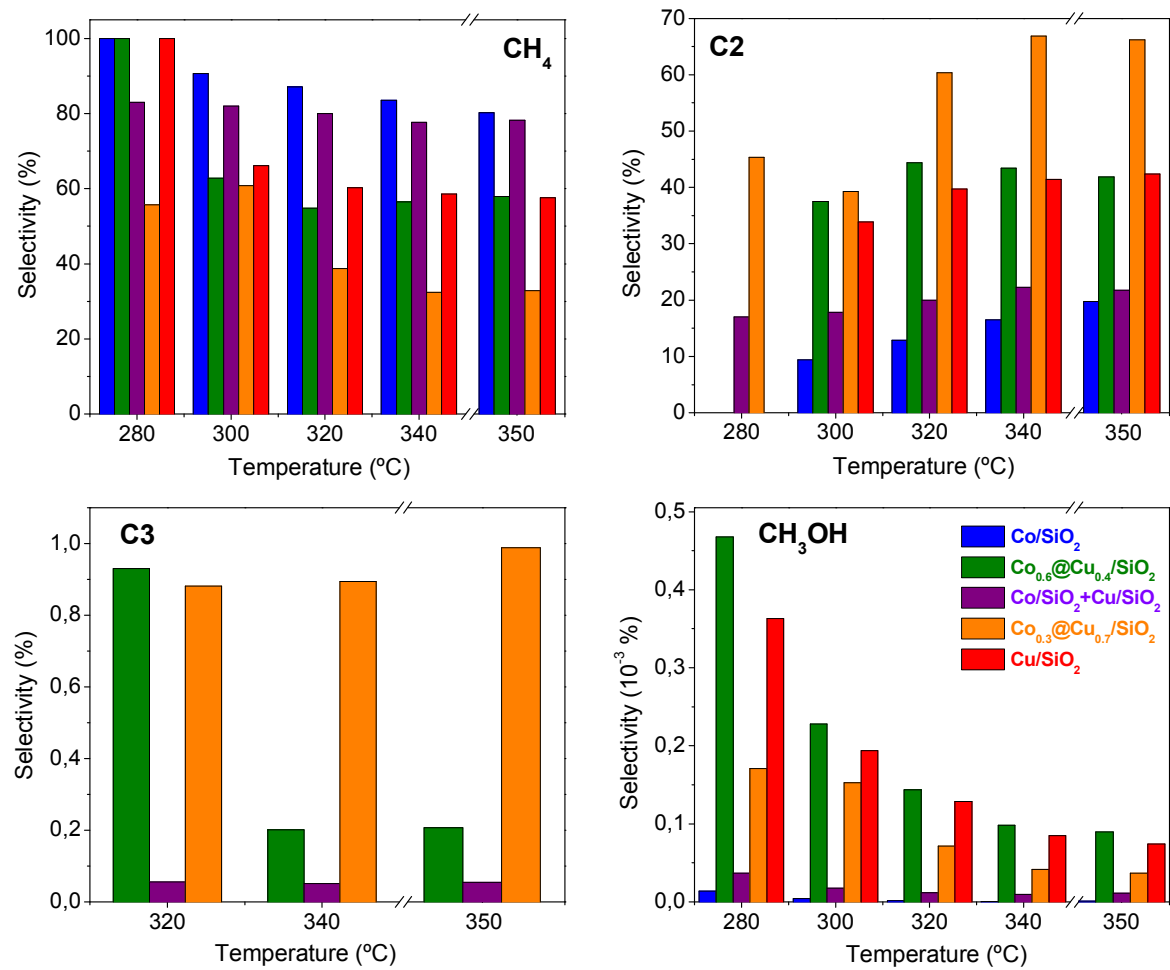

Figure 9. Relative selectivities related to hydrogenated products obtained from the $\mathrm{Co} / \mathrm{SiO}_{2}$, $\mathrm{Cu} / \mathrm{SiO}_{2}, \mathrm{Co} / \mathrm{SiO}_{2}+\mathrm{Cu} / \mathrm{SiO}_{2}, \mathrm{Co}_{0.6} @ \mathrm{Cu}_{0.4} / \mathrm{SiO}_{2}$ and $\mathrm{Co}_{0.3} @ \mathrm{Cu}_{0.7} / \mathrm{SiO}_{2}$ catalysts.

Catalysts were further analyzed after reaction. Figure 10a shows the XRD patterns of the initial $\mathrm{Co}_{0.3} @ \mathrm{Cu}_{0.7} \mathrm{NPs}$ and of the $\mathrm{Co}_{0.3} @ \mathrm{Cu}_{0.7} / \mathrm{SiO}_{2}$ catalyst after the reduction treatment and after catalytic test. Notice that the cubic structure of the NPs was conserved. The narrower peaks after reduction and after reaction are related to a better crystallinity of the material after thermal treatment of the sample at $350{ }^{\circ} \mathrm{C}$ and under 30 bar of pressure. On the other hand, single particle compositional analysis of the $\mathrm{Co}_{0.3} @ \mathrm{Cu}_{0.7}$ NPs supported on a silicon nitrate TEM grid and exposed to the oxidation, reduction and reaction conditions showed the core-shell structure not to stand the reaction conditions. During reaction conditions, the two metal phases separated to form non-symmetric bimetallic heterostructures (Figure 10b). 

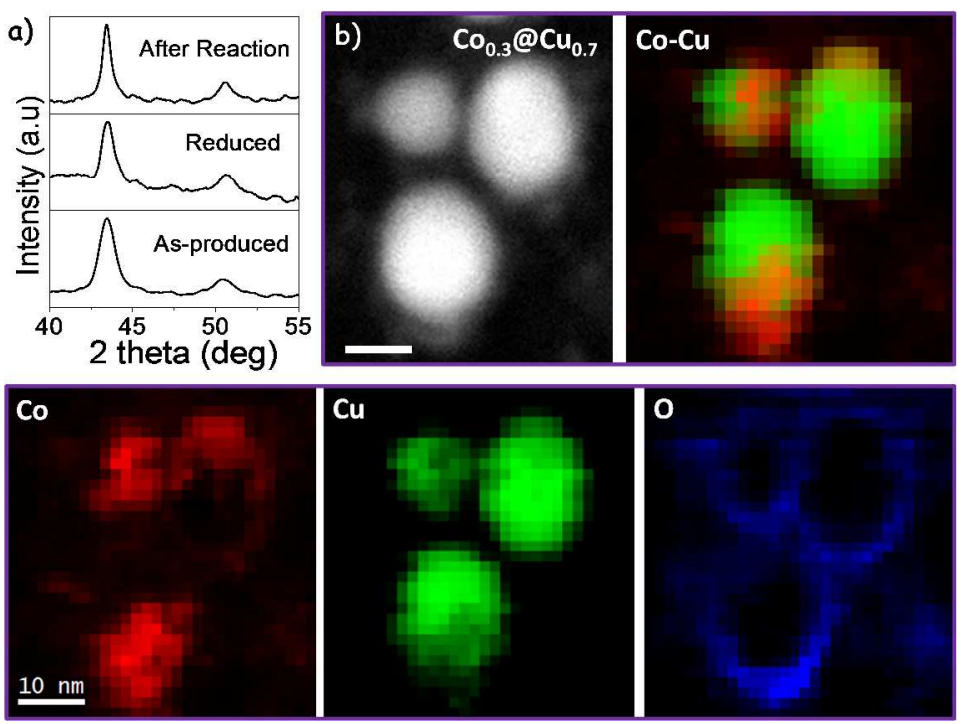

Figure 10. a) XRD patterns of the initial $\mathrm{Co}_{0.3} @ \mathrm{Cu}_{0.7} \mathrm{NPs}$ and of the $\mathrm{Co}_{0.3} @ \mathrm{Cu}_{0.7} / \mathrm{SiO}_{2}$ catalyst after the reduction treatment and after the catalytic test. B) HAADF-STEM micrograph and EELS chemical composition maps, $\mathrm{Co}$ (red), $\mathrm{Cu}$ (green) and $\mathrm{O}$ (blue), of three $\mathrm{Co}_{0.3} @ \mathrm{Cu}_{0.7} \mathrm{NPs}$ supported on a silicon nitride TEM grid and exposed to the consecutive, oxidation, reduction and reaction conditions. Scale bar $=10 \mathrm{~nm}$

\section{CONCLUSIONS}

A new colloidal synthesis route to produce $\mathrm{Co}-\mathrm{Cu}$ NPs with controlled composition based on the galvanic replacement of $\mathrm{Co}$ by $\mathrm{Cu}$ was detailed. This synthetic strategy allowed the preparation of $\mathrm{Co}-\mathrm{Cu}$ model catalysts with well controlled parameters to be studied in real working conditions. These catalysts were thoroughly characterized to understand the interactions originated at the nanoscale between the two metals. TPR profiles showed a synergistic effect on the reduction of cobalt and copper in $\mathrm{Co}-\mathrm{Cu} / \mathrm{SiO}_{2}$ catalysts. During oxidation and posterior reduction, a core-shell inversion was observed without coalescence or aggregation of the nanoparticles. We believe $\mathrm{Co}$ intermixed with $\mathrm{Cu}$ during the oxidation process and $\mathrm{Cu}$ reduced to 
the center of the NP during the reduction treatment, while Co migrated at its surface. Nevertheless, $\mathrm{N}_{2} \mathrm{O}$ chemisorption pointed out the accessibility of the copper within the reversed Co-Cu core-shell NPs. $\mathrm{CO}_{2}$ conversion tests showed that catalysts containing large and pure Co NPs were characterized by one order of magnitude higher total conversions. Nevertheless, a clear synergism between $\mathrm{Co}$ and $\mathrm{Cu}$ was shown by the different TPR profiles and catalytic behavior in $\mathrm{CO}_{2}$ hydrogenation; $\mathrm{Co}-\mathrm{Cu} / \mathrm{SiO}_{2}$ showed a better stability and higher relative selectivities to form C-C bonds and methanol than monometallic catalysts and the physical mixture $\mathrm{Co} / \mathrm{SiO}_{2}+\mathrm{Cu} / \mathrm{SiO}_{2}$. A more appropriate support than $\mathrm{SiO}_{2}$ and possibly larger Co domains would be necessary to improve both the total $\mathrm{CO}_{2}$ conversion and the selectivity towards high hydrocarbons and especially alcohols.

\section{AUTHOR INFORMATION}

\section{Corresponding Author}

*E-mail: narcis.homs@qi.ub.es

*E-mail: acabot@irec.cat

\section{Author Contributions}

The manuscript was written through contributions of all authors. All authors have given approval to the final version of the manuscript.

\section{ACKNOWLEDGMENT}

The research was supported by the European Regional Development Funds and the Spanish MICINN projects CSD2009-00050, MAT2014-52416-P and ENE2013-46624-C4-3-R. MI thanks AGAUR for her Beatriu de Pinós postdoctoral grant 2013 BP-A00344. JA and AG 
acknowledge the funding from the Spanish MINECO Severo Ochoa Excellence Program and Generalitat de Catalunya 2014SGR1638.

\section{ASSOCIATED CONTENT}

Supporting Information. ICP metal contents, $\mathrm{Cu}$ surface areas, thermogravimetry results, additional TEM and HRTEM micrograph, x-ray photoelectron spectroscopy (XPS) analysis of the material after rection and time evolution of total $\mathrm{CO}_{2}$ conversions. This material is available free of charge via the Internet at http://pubs.acs.org.

\section{REFERENCES}

(1) Somorjai, G. A.; Park, J. Y. Molecular Factors of Catalytic Selectivity. Angew. Chem., Int. Ed. 2008, 47, 9212-9228.

(2) Jia, C. J.; Schüth, F. Colloidal Metal Nanoparticles as a Component of Designed Catalyst. Phys. Chem. Chem. Phys. 2011, 13, 2457-2487.

(3) Zaera, F. Nanostructured Materials for Applications in Heterogeneous Catalysis. Chem. Soc. Rev. 2013, 42, 2746-2762.

(4) Gross, E.; Somorjai, G. A. Molecular Catalysis Science: Nanoparticle Synthesis and Instrument Development for Studies Under Reaction Conditions. J. Catal. 2015, 328, 91101.

(5) Yin, Y.; Alivisatos, A. P. Colloidal Nanocrystal Synthesis and the Organic-Inorganic Interface. Nature 2005, 437, 664-670. 
(6) Luo, Z.; Ibáñez, M.; Antolín, A. M.; Genç, A., Shavel, A.; Contreras, S.; Medina, F.; Arbiol, J.; Cabot, A. Size and Aspect Ratio Control of $\mathrm{Pd}_{2} \mathrm{Sn}$ Nanorods and Their Water Denitration Properties. Langmuir 2015, 31, 3952-3957.

(7) Yu, X.; Shavel, A.; An, X.; Luo, Z.; Ibáñez, M.; Cabot, A. The Effect of the Ga Content on the Photocatalytic Hydrogen Evolution of CuIn ${ }_{1-} \mathrm{Ga}_{\mathrm{x}} \mathrm{S}_{2}$ Nanocrystals. J. Am. Chem. Soc. 2014, 136, 9236-9239.

(8) Ibáñez, M.; Cabot, A. All Change for Nanocrystals. Science 2013, 340, 935-936.

(9) Kovalenko, M.V. et al. Prospects of Nanoscience with Nanocrystals. ACS Nano 2015, 9, 1012-1057.

(10) Nafria, R.; de la Piscina, P. R.; Homs, N.; Morante, J. R.; Cabot, A.; Diaz, U.; Corma, A. Embedding Catalytic Nanoparticles Inside Mesoporous Structures with Controlled Porosity: Au@TiO2.J.Mater.Chem.A 2013, 1, 14170-14176.

(11) Flox, C.; Rubio-Garcia, J.; Nafria, R.; Zamani, R.; Skoumal, M.; Andreu, T.; Arbiol, J.; Cabot, A.; Morante, J. R. Active Nano-CuPt ${ }_{3}$ Electrocatalyst Supported on Graphene for Enhancing Reactions at the Cathode in all-Vanadium Redox Flow Batteries. Carbon 2012, 50, 2372-2374.

(12) Herranz, T.; Deng, X.; Cabot, A.; Guo, J.; Salmeron, M. Influence of the Cobalt Particle Size in the CO Hydrogenation Reaction Studied by in Situ X-Ray Absorption Spectroscopy. J. Phys. Chem. B 2009, 113, 10721-10727.

(13) Kwangjin, A.; Somorjai, G. A. Nanocatalysis I: Synthesis of Metal and Bimetallic Nanoparticles and Porous Oxides and Their Catalytic Reaction Studies. Catal. Lett. 2015, 145, 233-248. 
(14) Wang, W.; Wang, S.; Ma, X.; Gong, J. Recent Advances in Catalytic Hydrogenation of Carbon Dioxide. Chem. Soc. Rev. 2011, 40, 3703-3727.

(15) Homs, N.; Toyir, J.; de la Piscina, P. R. Catalytic Processes for Activation of $\mathrm{CO}_{2}$. New and future Developments in Catalysis Elsevier, 2013.

(16) Centi, G.; Perathoner, S. Opportunities and Prospects in the Chemical Recycling of Carbon Dioxide to Fuels. Catal. Today 2009, 148, 191-205.

(17) Ma, J.; Sun, N.; Zhang, X.; Zhao, N.; Xiao, F.; Wei, W.; Sun, Y. A Short Review of Catalysis for $\mathrm{CO}_{2}$ Conversion. Catal. Today 2009, 148, 221-231.

(18) Nieskens, D. L.; Ferrari, D.; Liu, Y.; Kolonko, R. The Conversion of Carbon Dioxide and Hydrogen into Methanol and Higher Alcohols. Catal. Commun. 2011, 14, 111-113.

(19) Courty, P.; Durand, D.; Freund, E.; Sugier, A. $\mathrm{C}_{1}-\mathrm{C}_{6}$ Alcohols From Synthesis Gas on Copper-Cobalt Catalysts. J. Mol. Catal. 1982, 17, 241-254.

(20) Dalmon, J. A.; Chaumette, P.; Mirodatos, C. Higher Alcohols Synthesis on Cobalt Based Model Catalysts. Catal. Today 1992, 15, 101-127.

(21) Mouaddib, N.; Perrichon, V.; Martin, G. A. Characterization of Copper-Cobalt Catalysts for Alcohol Synthesis from Syngas. Appl. Catal. A 1994, 118, 63-72.

(22) Bailliard-Letournel, R. M.; Cobo, A. J. G.; Mirodatos, C.; Primet, M.; Dalmon, J. A. About the Nature of the Co- $\mathrm{Cu}$ Interaction in Co-Based Catalysts for Higher Alcohols Synthesis. Catal. Lett. 1989, 2, 149-156.

(23) Cao, R.; Pan, W. X.; Griffin, G. L. Direct Synthesis of Higher Alcohols Using Bimetallic Copper/Cobalt Catalysts. Langmuir 1988, 4, 1108-1112. 
(24) Liu, G., Niu, T., Pan, D., Liu, F., Liu, Y. Preparation of Bimetal Cu-Co Nanoparticles Supported on Meso-Macroporous $\mathrm{SiO}_{2}$ and Their Application to Higher Alcohols Synthesis from Syngas. Appl. Catal. A 2014, 483, 10-18.

(25) Xiang, Y.; Barbosa, R.; Kruse, N. Higher Alcohols Through CO Hydrogenation over CoCu Catalysts: Influence of Precursor Activation. ACS Catal. 2014, 4, 2792-2800.

(26) Nilekar, A. U.; Alayoglu, S.; Eichhorn, B.; Mavrikakis, M. Preferential CO Oxidation in Hydrogen: Reactivity of Core-Shell Nanoparticles. J. Am. Chem. Soc. 2010, 132, 74187428.

(27) Subramanian, N. D.; Balaji, G.; Kumar, C. S. S. R.; Spivey, J. Development of CobaltCopper Nanoparticles as Catalysts for Higher Alcohol Synthesis from Syngas. J. Catal. Today 2009, 147, 100-106.

(28) Alayoglu, S.; Beaumont, S. K.; Melaet, G.; Lindeman, A. E.; Musselwhite, N.; Brooks, C. J.; Somorjai, G. A. Surface Composition Changes of Redox Stabilized Bimetallic CoCu Nanoparticles Supported on Silica under $\mathrm{H}_{2}$ and $\mathrm{O}_{2}$ Atmospheres and During Reaction between $\mathrm{CO}_{2}$ and $\mathrm{H}_{2}$ : In Situ X-ray Spectroscopic Characterization. J. Phys. Chem. C 2013, 117, 21803-21809.

(29) Khodakov, A. Y.; Chu, W.; Fongarland, P. Advances in the Development of Novel Cobalt Fischer-Tropsch Catalysts for Synthesis of Long-Chain Hydrocarbons and Clean Fuels. Chem. Rev. 2007, 107, 1692-1744.

(30) Spivey, J. J.; Egbebi, A. Heterogeneous Catalytic Synthesis of Ethanol from BiomassDerived Syngas. Chem. Soc. Rev. 2007, 36, 1514-1528.

(31) Gupta, M.; Smith, M. L.; Spivey, J. J. Heterogeneous Catalytic Conversion of Dry Syngas to Ethanol and Higher Alcohols on Cu-based Catalysts. ACS Catal. 2011, 1, 641-656. 
(32) Waugh, K. C. Methanol Synthesis. Catal. Today 1992, 15, 51-75.

(33) Klier, K. Methanol Synthesis. Adv. Catal. 1982, 31, 243-313.

(34) Toyir, J.; de la Piscina, P. R.; Fierro, J. L. G.; Homs, N. Highly Effective Conversion of $\mathrm{CO}_{2}$ to Methanol over Supported and Promoted Copper-based Catalysts: Influence of Support and Promoter. Appl. Catal. B 2001, 29, 207-215.

(35) Iablokov, V.; Beaumont, S. K.; Alayoglu, S.; Pushkarev, V. V.; Specht, C.; Gao, J.; Somorjai, G. A. Size-Controlled Model Co Nanoparticle Catalysts for $\mathrm{CO}_{2}$ Hydrogenation: Synthesis, Characterization, and Catalytic Reactions. Nano Lett. 2012, 12, 3091-3096.

(36) Melaet, G., Ralston, W. T.; Li, C. S.; Alayoglu, S.; An, K.; Musselwhite, N.; Somorjai, G. A. Evidence of Highly Active Cobalt Oxide Catalyst for the Fischer-Tropsch Synthesis and $\mathrm{CO}_{2}$ Hydrogenation. J. Am. Chem. Soc. 2014, 136, 2260-2263.

(37) Melaet, G.; Lindeman, A. E.; Somorjai, G. A. Cobalt Particle Size Effects in the FischerTropsch Synthesis and in the Hydrogenation of $\mathrm{CO}_{2}$ Studied with Nanoparticle Model Catalysts on Silica. Top. Catal. 2014, 57, 500-507.

(38) Wang, Z. J.; Skiles, S.; Yang, F.; Yan, Z.; Goodman, D. W. Particle Size Effects in Fischer-Tropsch Synthesis by Cobalt. Catal. Today 2012, 181, 75-81.

(39) Tuxen, A.; Carenco, S.; Chintapalli, M.; Chuang, C. H.; Escudero, C.; Pach, E.; Salmeron, M. Size-Dependent Dissociation of Carbon Monoxide on Cobalt Nanoparticles. J. Am. Chem. Soc. 2013, 135, 2273-2278.

(40) Natesakhawat, S.; Lekse, J. W.; Baltrus, J. P.; Ohodnicki Jr, P. R.; Howard, B. H.; Deng, X.; Matranga, C. Active Sites and Structure-Activity Relationships of Copper-Based Catalysts for Carbon Dioxide Hydrogenation to Methanol. ACS Catal. 2012, 2, 16671676. 
(41) Prieto, G.; Beijer, S.; Smith, M. L.; He, M., Au, Y.; Wang, Z.; Bruce. D.A.; de Jong. K.P.; Spivey. J.J.; de Jongh, P. E. Design and Synthesis of Copper-Cobalt Catalysts for the Selective Conversion of Synthesis Gas to Ethanol and Higher Alcohols. Angew. Chem., Int. Ed. 2014, 53, 6397-6401.

(42) Carenco, S.; Tuxen, A.; Chintapali, M.; Pach, E.; Escudero, C.; Ewers, T. D.; Jiang, P.; Borondics, F.; Thornton, G.; Alivastos, A. P.; Bluhm, H.; Guo, J.; Salmeron, M. Dealloying of Cobalt from CuCo Nanoparticles Under Syngas Exposure. J. Phys. Chem. C 2013, 117, 6259-6266.

(43) Puntes, V. F.; Krishnan, K. M.; Alivisatos, A. P. Colloidal Nanocrystal Shape and Size Control: the Case of Cobalt. Science 2001, 291, 2115-2117.

(44) Hung, L. I.; Tsung, C. K.; Huang, W.; Yang, P. Room-Temperature Formation of Hollow $\mathrm{Cu}_{2} \mathrm{O}$ Nanoparticles. Adv. Mater. 2010, 22, 1910-1914.

(45) Rioux, R. M.; Song, H.; Hoefelmeyer, J. D.; Yang, P.; Somorjai, G. A. High-Surface-Area Catalyst Design: Synthesis, Characterization, and Reaction Studies of Platinum Nanoparticles in Mesoporous SBA-15 Silica. J. Phys. Chem. B 2005, 109, 2192-2202.

(46) Xia, X.; Wang, Y.; Ruditskiy, A.; Xia, Y. 25th Anniversary Article: Galvanic Replacement: A Simple and Versatile Route to Hollow Nanostructures with Tunable and Well-Controlled Properties. Adv. Mater. 2013, 25, 6313-6333.

(47) Dinega, D. P.; Bawendi, M. G. A Solution-Phase Chemical Approach to a new Crystal Structure of Cobalt. Angew. Chem., Int. Ed. 1999, 38, 1788-1791.

(48) ASM Handbook; Alloy Phase Diagrams. ASM International: OH 1992; Vol.3. 
(49) Ahmed, J.; Ganguly, A.; Saha, S.; Gupta, G.; Trinh, P.; Mugweru, A. M.; Ganguli, A. K. Enhanced Electrocatalytic Activity of Copper-Cobalt Nanostructures. J. Phys. Chem. C 2011, 115, 14526-14533.

(50) Li, G.; Wang, Q.; Li, D.; Lü, X.; He, J. Structure Evolution During the Cooling and Coalesced Cooling Processes of $\mathrm{Cu}-\mathrm{Co}$ Bimetallic Clusters. Phys. Lett. A 2008, 372, 67646769.

(51) de la Peña O'Shea, V. A.; Homs, N.; Pereira, E. B.; Nafria, R.; Ramírez de la Piscina, P. X-ray Diffraction Study of $\mathrm{Co}_{3} \mathrm{O}_{4}$ Activation Under Ethanol Steam-Reforming. Catal. Today 2007, 126, 148-152.

(52) Khodakov, A. Y., Lynch, J., Bazin, D., Rebours, B., Zanier, N., Moisson, B., Chaumette, P. Reducibility of Cobalt Species in Silica-Supported Fischer-Tropsch Catalysts. J. Catal. 1997, 168, 16-25.

(53) Smith, M. L.; Campos, A.; Spivey, J. J. Reduction Processes in $\mathrm{Cu} / \mathrm{SiO}_{2}, \mathrm{Co} / \mathrm{SiO}_{2}$, and $\mathrm{CuCo} / \mathrm{SiO}_{2}$ Catalysts. Catal. Today 2012, 182, 60-66.

(54) Fierro, G.; Jacono, M. L.; Inversi, M.; Dragone, R.; Porta, P. TPR and XPS Study of Cobalt-Copper Mixed Oxide Catalysts: Evidence of a Strong $\mathrm{Co}-\mathrm{Cu}$ Interaction. Top. Catal. 2000, 10, 39-48.

(55) Deng, S.; Chu, W.; Xu, H.; Shi, L.; Huang, L. Effects of Impregnation Sequence on the Microstructure and Performances of $\mathrm{Cu}-\mathrm{Co}$ Based Catalysts for the Synthesis of Higher Alcohols. J. Nat. Gas Chem. 2008, 17, 369-373.

(56) Cesar, D. V.; Peréz, C. A.; Salim, V. M. M.; Schmal, M. Stability and Selectivity of Bimetallic $\mathrm{Cu}-\mathrm{Co} / \mathrm{SiO}_{2}$ Catalysts for Cyclohexanol Dehydrogenation. Appl. Catal. A 1999, 176, 205-212. 
(57) Yin, Y.; Erdonmez, C. K.; Cabot, A.; Hughes, S.; Alivisatos, A. P. Colloidal Synthesis of Hollow Cobalt Sulfide Nanocrystals. Adv. Funct. Mater. 2006, 16, 1389-1399.

(58) Ibáñez, M.; Fan, J.; Li, W.; Cadavid, D.; Nafria, R.; Carrete, A.; Cabot, A. Means and Limits of Control of the Shell Parameters in Hollow Nanoparticles Obtained by the Kirkendall Effect. Chem. Mater. 2011, 23, 3095-3104.

(59) Cabot, A.; Ibáñez, M.; Guardia, P.; Alivisatos, A. P. Reaction regimes on the synthesis of holoow particles by the Kirkendall effect, J. Am. Chem. Soc. 2009, 131, 11326-11328.

(60) Cabot, A.; Puntes, F. F.; Shevchenko, E.; Yin, Y.; Balcells, L.; Marcus, M. A.; Hughes, S. M.; Alivisatos, A. P.; Vacancy coalescence during oxidation of iron nanoparticles, J. Am. Chem. Soc. 2007, 129, 10358-10360.

(61) Evans, J. W.; Wainwright, M. S.; Bridgewater, A. J.; Young, D. J. On the Determination of Copper Surface Area by Reaction with Nitrous Oxide. Appl. Catal. 1983, 7, 75-83.

(62) Robinson, W. R. A. M.; Mol, J. C. Characterization and Catalytic Activity of Copper/Alumina Methanol Synthesis Catalysts. Appl. Catal. 1988, 44, 165-177.

(63) Mahdavi, V.; Peyrovi, M. H. Synthesis of $\mathrm{C}_{1}-\mathrm{C}_{6}$ Alcohols Over Copper/Cobalt Catalysts: Investigation of the Influence of Preparative Procedures on the Activity and Selectivity of $\mathrm{Cu}-\mathrm{Co}_{2} \mathrm{O}_{3} / \mathrm{ZnO}, \mathrm{Al}_{2} \mathrm{O}_{3}$ Catalyst. Catal. Commun. 2006, 7, 542-549.

(64) Lahtinen, J.; Anraku, T.; Somorjai, G. A. C, $\mathrm{CO}$ and $\mathrm{CO}_{2}$ Hydrogenation on Cobalt Foil Model Catalysts: Evidence for the Need of CoO Reduction. Catal. Lett. 1994, 25, 241-255.

(65) Sandoval, M. J.; Bell, A. T. Temperature-Programmed Desorption Studies of the Interactions of $\mathrm{H}_{2}, \mathrm{CO}$, and $\mathrm{CO}_{2}$ with $\mathrm{Cu} / \mathrm{SiO}_{2} . J$. Catal. 1993, 144, $227-237$. 
(66) Barbier, A.; Tuel, A.; Arcon, I.; Kodre, A.; Martin, G. A. Characterization and Catalytic Behavior of $\mathrm{Co} / \mathrm{SiO}_{2}$ Catalysts: Influence of Dispersion in the Fischer-Tropsch Reaction. $J$. Catal. 2001, 200, 106-116.

(67) Weatherbee, G. D.; Bartholomew, C. H. Hydrogenation of $\mathrm{CO}_{2}$ on Group VIII Metals: IV. Specific Activities and Selectivities of Silica-Supported Co, Fe, and Ru. J. Catal. 1984, $87,352-362$.

(68) Fujitani, T.; Nakamura, I.; Uchijima, T.; Nakamura, J. The Kinetics and Mechanism of Methanol Synthesis by Hydrogenation of $\mathrm{CO}_{2}$ over a Zn-deposited $\mathrm{Cu}$ (111) Surface. Surf. Sci. 1997, 383, 285-298.

(69) Clancy, P.; Breen, J. P.; Ross, J. R. The Preparation and Properties of Coprecipitated Cu$\mathrm{Zr}-\mathrm{Y}$ and $\mathrm{Cu}-\mathrm{Zr}-\mathrm{La}$ Catalysts used for the Steam Reforming of Methanol. Catal. Today 2007, 127, 291-294.

(70) Chinchen, G. C.; Waugh, K. C.; Whan, D. A. The Activity and State of the Copper Surface in Methanol Synthesis Catalysts. Appl. Catal. 1986, 25, 101-107.

(71) Fujitani,T.; Nakamura, J. The Effect of $\mathrm{ZnO}$ in Methanol Synthesis Catalysts on $\mathrm{Cu}$ Dispersion and the Specific Activity. Catal. Lett. 1998, 56, 119-124.

(72) Robbins, J. L.; Iglesia, E.; Kelkar, C. P.; DeRites, B. Methanol Synthesis over Cu/SiO 2 Catalysts. Catal. Lett. 1991, 10, 1-10.

Insert Table of Contents Graphic and Synopsis Here 


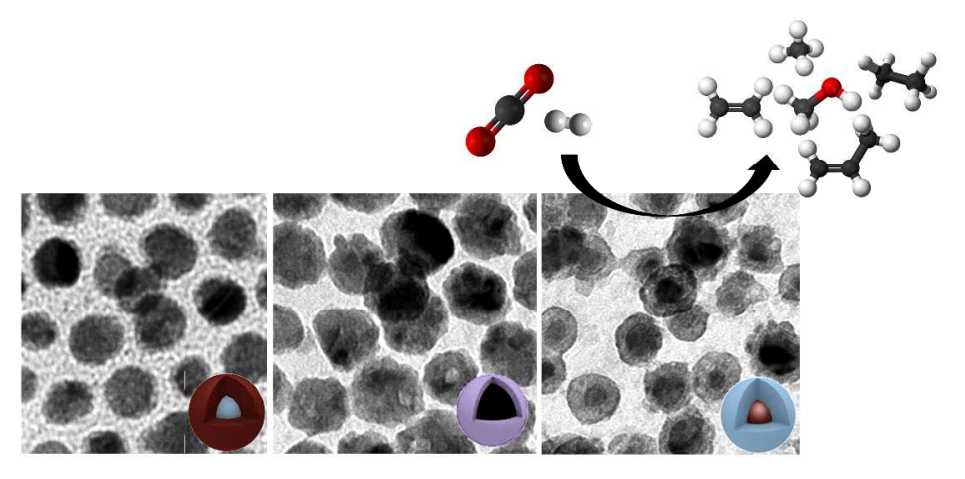

14

15

16

17

18

19

20

21

22

23

24

25

26

27

28

29

30

31

32

33

34

35

36

37

38

39

40

41

42

43

44

45

46

47

48

49

50

51

52

53

54

55

56

57

58

59

60

ACS Paragon Plus Environment 